\title{
Yapay Zekâ ve Tıbbi Görüntüleme Teknolojilerine Genel Bakış
}

\section{An Overview of Artificial Intelligence and Medical Imaging Technologies}

\author{
Furkan Atlan ${ }^{1}$ (1), İhsan Pençe ${ }^{2}$ (1)
}

${ }^{1}$ (Doktora Öğrencisi), Burdur Mehmet Akif Ersoy Üniversitesi, Sosyal Bilimler Enstitüsü, Yönetim Bilişim Sistemleri, Burdur, Türkiye

${ }^{2}$ (Dr. Öğr. Üyesi), Burdur Mehmet Akif Ersoy Üniversitesi Bucak Teknoloji Fakültesi, Yazılım Mühendisliği Bölümü, Burdur, Türkiye

ORCID: F.A. 0000-0003-1602-1941; İ.P. 0000-0003-0734-3869

Corresponding author:

Furkan ATLAN

Burdur Mehmet Akif Ersoy Üniversitesi, Sosyal Bilimler Enstitüsü, Yönetim Bilișim Sistemleri, Burdur, Türkiye

E-mail address: furkanatlann@gmail.com

Submitted: 20.10 .2020

Revision Requested: 21.12 .2020

Last Revision Received: 15.01.2021

Accepted: 16.01.2021

Published Online: 01.03.2021

Citation: Atlan, F. ve Pence, I. (2021). Yapay zekâ ve tıbbi görüntüleme teknolojilerine genel bakıș. Acta Infologica, 5(1), 207-230. https://doi.org/10.26650/acin.813736

\section{$\ddot{O z Z}$}

Günümüzde yapay zekânın kullanıldığı alanlar her geçen gün artmakta olup, bu alanlardan biri de sağlık sektörüdür. Özellikle görüntü işlemede oldukça başarılı sonuçlar vermesi sebebi ile yapay zekânın bir alt dalı olan derin öğrenme, tıbbi görüntülerin işlenmesinde ve yorumlanmasında sıkça tercih edilmektedir. Her ne kadar tıbbi görüntüleme teknolojilerinin gelişmesi ile hastalık tanısı ve teşhisi gibi işlemlerdeki doğruluk oranı artsa da bu görüntülerin uzmanlar tarafından doğru bir şekilde yorumlanması zaman açısından maliyetli ve tedavi süreci açısından da olumsuz bir durum sergilemektedir. Bu sebeple, yapay zekâ kullanılarak otomatik tanı sistemleri oluşturulmakta ve bu sistemler gelişen teknoloji ve algoritmalar sayesinde her geçen gün ilerleme kat etmektedir. Çalışmanın amacı, tıbbi görüntülemede yapay zekâ kullanımı konusunda tüm bileşenlerin ele alınarak bilgi verilmesi ve bu alanda çalışma yapacak araştırmacılara bir temel teşkil edecek bir alt yapı oluşturmaktır. Bunun sağlanması için yapay zekâ ve tıbbi görüntüleme konusu öncelikle ayrı bir şekilde ele alınmış, tıbbi görüntüleme teknolojileri kapsamlı bir şekilde anlatılmış ve tıbbi görüntülemede yapay zekâ kullanımının mevcut durumu, geleceği, sorunları ve çözümleri açık bir şekilde belirtilmiştir. Son olarak yapay zekâ teknikleri ile tıbbi görüntülerin işlenmesine dair çalışmalar verilerek çalışmanın teorik anlam bütünlüğü sağlanmıştır.

Anahtar kelimeler: Tibbi görüntüleme teknolojileri, Yapay zekâ, Bilgisayar destekli tanı sistemleri

\section{ABSTRACT}

Nowadays, the use of artificial intelligence is increasing steadily, particularly in the health sector. Deep learning, which is a sub-branch of artificial intelligence, is frequently preferred in the processing and interpretation of medical images, because it provides fruitful outcomes in image processing. Despite the development in medical imaging technologies and the increasing accuracy rate of disease diagnosis, accurate interpretation of these images by experts is time consuming, and unfavorable conditions may arise during treatment. For this reason, automated diagnostic systems are created using artificial intelligence, and these systems are improving gradually, owing to the evolution of several technologies and algorithms. This study aimed to provide information on the use of artificial intelligence in medical imaging with due consideration of all factors and create a base infrastructure for researchers in this field. To achieve this, previously artificial intelligence and medical imaging were discussed separately, placing more emphasis on medical imaging technologies. However, at present, potential problems and solutions in the use of artificial intelligence in medical imaging are clearly stated. In conclusion, by conducting more studies on the processing of medical images using artificial intelligence, the theoretical integrity of this field will become possible. Keywords: Medical imaging technologies, Artificial intelligence, Computer-aided diagnosis systems 


\section{GİRIŞ}

Günümüzde, yapay zekânın kullanım alanları gittikçe genişlemekte ve bu alanlarda yapılan çalışmalar da artmaktadır. Özellikle görüntü işleme alanında yapay zekânın alt disiplinlerinden biri olarak karşılaşılan derin öğrenme ve tıbbi görüntü formatlarının dijitalleşmesi sayesinde yapay zekânın sağlık sektöründe kullanımı oldukça dikkat çekici konular arasında yer almaktadir.

Her yıl milyonlarca insanın ölümüne neden olan kanser (Bray ve ark., 2018) vb. hastalıkların önceden tespiti, sınıflandırılması ve bunların otomatikleştirilmesi ile ilgili çalışmalar (Kiani ve ark., 2020; Ghoneim, Muhammad ve Hossain, 2020; Dandıl ve Serin, 2020; Öztad, 2020), tıbbi görüntülemede yapay zekâ kullanımının ihtiyacını ve önemini ortaya koymaktadır. Yapay zekânın bu alandaki kullanımı tüm tarafların yani hastaların, doktorların, klinisyenlerin vd. sağlık çalışanları ile yapay zekâ geliştiricilerinin katılımı ile ilerleyen bir süreçten ibaret olarak görülebilir (Al-shamasneh ve Obaidellah, 2017; Greenspan, Van Ginneken ve Summers, 2016). Tibbi görüntülemede yapay zekâ kullanımı sadece dijital tıbbi görüntülerin yapay zekâ teknikleri ile ön işlenmesinden ibaret değildir. Burada asıl amaç, elle işlenmesi zaman ve maliyet açısından oldukça pahalıya mâl olan bir süreci hastaların, sağlık çalışanlarının ve araştırma görevini yürüten üçüncü taraf kişi ya da kurumların lehine dönüştürmektir. Geliştirilecek uygulama ve/veya modellerin, radyolog, patolog gibi işin uzmanlarına danış1larak tüm süreç boyunca karşılıklı bilgi alışverişinde bulunularak hem sağlık çalışanlarının bilgilerinden faydalanılıp onların tecrübesinin oluşturulacak modele yansıtılarak en başarılı modelin ortaya konulması hem de elde edilecek verilere erişimde kolaylık sağlanması ve bunlar yapılırken kişisel mahremiyetin ihlal edilmemesi, günümüzde tıbbi görüntülemede yapay zekâ kullanımında en sık karşılaşılan sorunlar arasındadır (Litjens ve ark., 2017; Fotin, Yin, Haldankar, Hoffmeister ve Periaswamy, 2016).

Bu çalışmada yapay zekâ ve onun alt disiplinleri ile tıbbi görüntüleme teknolojilerine ait kavramlar açıklanmakta, yapay zekânın tıbbi görüntüleme alanında kullanımı ve bu alanda yapılan çalışmaların başarı durumları, sonuçları ve geliştirilen modeller hakkında bilgi verilmektedir. Bu çalışmanın amacı, yapay zekânın tıbbi görüntülemede kullanılması ile ilgili yapılacak çalışmalara temel teşkil edecek bilgilerin verilmesi, literatürde açık bir şekilde ele alınmayan tıbbi görüntülemede yapay zekâ kullanımının mevcut durumu, farklı enerji türleri kullanan tıbbi görüntüleme teknolojileri alanında yapılmış başarılı çalışmalara ait bilgi ve sonuçların sunulmasıdır. Çalışmada ele alınan konular kapsamlı ve açıklayıcı bir şekilde birlikte ele alan bir çalışmanın bulunmaması ve özellikle nükleer tıp görüntüleme konusundaki çalışmaların yetersiz olması bu çalışmanın önemini ve özgünlüğü ortaya koymaktadır.

\section{GENEL KAVRAMLAR}

Bu bölümde, çalışmanın amacının anlaşılması ve misyonunun yerine gelmesini sağlamak amacıyla yapay zekâ ve tıbbi görüntülemeye dair temel ve ilişkili kavramlar açıklanmaktadır.

\subsection{Yapay Zekâ}

Zekâ, Arapça bir kelimedir ve Türk Dil Kurumu’na (TDK) göre zekâ: ’İnsanın düşünme, akıl yürütme, objektif gerçekleri algılama, yargılama ve sonuç çıkarma yeteneklerinin tamamı, anlak, dirayet, zeyreklik, feraset" olarak tanımlanmaktadır (https://www.sozluk.gov.tr).

Yapay zekâ ve ondan türemiş diğer kollara ait kavramların tek bir tanımı yoktur. Ancak yapılan tanımlamaların özeti olarak aşağıdaki gibi bir kavramsal çerçeve çizilebilir.

Yapay Zekâ, farklı eylemleri ve görevleri zeki bir canlı gibi yerine getiren makine ve sistemlerin meydana getirilmesi ile ilgilenen genel bir teknolojidir. Bir terim olarak yapay zekâyı tanımlayan ilk kişi John McCarthy’dir. McCarthy’e (1955) göre yapay zekânın amacı, “zeki gibi davranan makineler geliştirmektir.” (Ertel, Black ve Mast, 2017).

Makine Öğrenmesi, bilgisayarların veriden (data) kurallar çıkararak kendi kendilerine öğrenmelerini ve bu sürecin gelişmesini sağlayan bir yaklaşımdır (Kubat, 2018). 
Derin Öğrenme, 2012 yılında ImageNet adı verilen çok büyük sayıdaki etiketli bir veri setini içerisinde yer alan görsellerin içeriğini (sınıflandırılmasını) tahmin etmek için ImageNet 2012 yarışmasında (challenge) (Deng, ve ark., 2012; https://www. kdnuggets.com/) AlexNet (Krizhevsky, Sutskever ve Hinton, 2012) adı verilen bir derin öğrenme modelinin \%15.3 hata oranı elde ederek görselleri doğru bir şekilde sınıflandırması ile tekrar gündeme gelmiş bir kavramdır (https://www.economist. com).

Derin Öğrenme, -ilk ortaya çıkışı ve geliştirilmesi itibari ile- özellikle görseller arasındaki örüntülerin tanınmasında, özniteliklerin çıkarımında, sınıflandırılmasında vb. işlemleri için geliştirilmiş bir yaklaşımdır ve yapay zekânın bir alt dalıdır (Gulli, Kapoor ve Pal, 2019). Ancak son yıllarda derin öğrenmenin kullanım alanları, konuşma sinyallerinin yok edilmesinden genlerin kümelenme modellerinin keşfine kadar farklı alanlara yayılmıştır (Wang ve Raj, 2017).

Günümüzde ImageNet veri seti ile yapılan çalışmalarda, geliştirilen yeni modeller sayesinde Top-1 doğruluk (accuracy) oranı (sınıflandırma çıktısının en yüksek olasılığa sahip tek çıktı ile eşleşmesi) \%88.5 ve Top-5 doğruluk (accuracy) oranı (sınıflandırma çıktısının en yüksek olasılığa sahip 5 çıktıdan biri ile eşleşmesi) \%98.7 oranına ulaşmıştır (https://paperswithcode. com).

\subsection{Tıbbi Görüntüleme}

Tıbbi görüntüleme (medical imaging), vücudun içyapılarının (doku, organ) analiz ve müdahale için farklı enerji türleri ile görüntülenmesini sağlamak amacıyla kullanılan teknikler ve yapılan işlemler bütünüdür (Bankman, 2009).

İnsan vücudunun tıbbi açıdan görüntülenmesi için enerjiye ihtiyaç duyulmaktadır. Farklı görüntüleme tekniklerinde farklı enerji türleri kullanılmaktadır. Örneğin; endoskopi, gastroenteroloji ve ışık mikroskopisi olarak da adlandırılan patolojide enerji türü olarak görünür 1şık (visible light) kullanılmaktadır. Radyoloji tabanlı görüntüleme teknikleri olan mamografi, bilgisayarlı tomografide (BT) enerji türü olarak X-ışınları kullanılmaktadır. Manyetik rezonans görüntülemede (MRI) enerji türü olarak radyo frekansları kullanılmaktadır. Nükleer tıp görüntülemede enerji türü olarak gama ışınları kullanılmaktadır. Ultrason görüntülerinde ise enerji türü olarak yüksek frekanslı ses dalgaları kullanılmaktadır (Bushberg, Seibert, Leidholdt Jr, Boone ve Goldschmidt Jr, 2011).

Nükleer tıp görüntülemenin aksine diğer bütün tıbbi görüntüleme tekniklerinde görüntüleme işleminin gerçekleşmesi, enerjinin vücuda nüfuz etmesi ile mümkündür. Vücuda gönderilen madde, vücut tarafından emilim ya da saçılma yoluyla kabul edilir. Vücudun içerisine giren bu madde ile vücudun içyapısı görüntülenebilir. Nükleer tıp görüntüleme de ise ajan olarak adlandırılan bir radyo aktif madde vücuda enjekte edilir veya ağız yolu ile yutulur. Daha sonra görüntüleme işlemi gerçekleştirilir. Görüntü elde edildikten sonra, tıbbi görüntünün tanısal bir fayda sağlaması yani hastalık veya kişinin mevcut durumu hakkında nitelikli bilgi vermesi görüntünün teknik kalitesi ve görüntünün elde edilme süreci ile doğrudan ilişkilidir. Daha uzun süre ve hastanın daha çok radyasyona maruz kalması ile daha kaliteli bir tıbbi görüntü elde edilebilir ancak bu durum hem uzmanlar hem de hasta açısından pek de kabul görmeyen bir durumdur. Bu sebeple tıbbi görüntülemede eğer enerji türü radyasyon ise radyasyona maruz kalma süresi ile tıbbi görüntünün kalitesi arasında bir denge gözetilmektedir (Bushberg, Seibert, Leidholdt Jr, Boone ve Goldschmidt Jr, 2011; Webb ve Flower, 2016).

\subsubsection{Tıbbi Görüntüleme Teknikleri}

Tıbbi görüntüleme, birçok hastalığın tanı, tedavi yöntemi ve teşhis gibi aşamalarında kullanılmaktadır. Tıbbi görüntüleme, yıllardır kanserin erken teşhis, tanı ve tedavi aşamalarının çok önemli bir parçası haline gelmiştir. Tıbbi görüntüleme sadece kanserin teşhisinde değil tedavi aşamasında hastalığın ne denli ilerlediği ve nasıl bir yayılım izlediği ile de ilgili bilgiler vermektedir.

Enerjilerin türleri ve elde etme teknolojileri değiştirilerek farkı tıbbi görüntüler elde edilebilir. Farklı görüntü yapma yöntemleri literatürde "yöntem (modalities)" olarak adlandırılmaktadır (Bushberg, Seibert, Leidholdt Jr, Boone ve Goldschmidt Jr, 2011). 


\subsubsection{Radyografi}

Radyografi, Alman fizikçi Wilhelm Conrad Röntgen tarafından 1895 yılında icat edilen ilk tıbbi görüntüleme teknolojisidir.

Röntgen, bir laboratuvar çalışmasında yüksek gerilimli elektrik akımını “Crooks” adı verilen tüpten geçirdiği zaman bir cam kavanoz içerisindeki kristallerde parıltılar gözlemlemiştir. O zamana kadar keşfedilmemiş bu parıltılara sebep olan 1şınlara ise bilinmeyen ışın anlamına gelen "X-1şınları" adı verilmiştir. Crooks tüplerinden yüksek gerilimli elektrik akımları geçtiğinde bir ekranda parıltılar meydana getiren X 1şınlarının, farklı cisimleri farklı derecelerde geçme özelliği olduğunu ve bu parıltıların (görüntülerin) kurşun levhalar ile depolanabildiğini fark eden Röntgen eliyle tuttuğu kurşun levhalardan ekrana yansıyan gölge de kendi parmaklarının görüntüsü görmüştür. Daha sonra eşinin elini fotoğraf plağı bulunan bir kasetin üzerine yerleştirerek üzerinde eşinin yüzüğünün de bulunduğu ilk röntgen görüntüsünü elde etmiştir (Ehrlich ve Daly, 2008; Arslan, 2010). Röntgen sayesinde insan anatomisi ilk defa radyogram olarak görüntülenmiştir. Şekil 1'de ilk radyogram görüntü olan, Wilhelm Conrad Röntgen’in eşinin elinin radyografik görüntüsü gösterilmektedir.

Radyografi teknolojisi sayesinde radyoloji alanı oluşmuş ve bu alanda uzman olan radyologlar yetişmiştir. Radyografi, hastanın bir tarafında X-1şını kaynağı ve hastanın diğer tarafında bir X-1şını detektörü ile yapılır. X-1şını tüpü tarafından çok kısa süreli ( 0.5 saniyeden az) bir nabız atımı, X-ışınlarının çok büyük bir bölümü hasta üzerinde etkileşir ve röntgenlerin bir kısmı hastadan geçerek radyogram görüntünün oluştuğu detektöre ulaşır. Hastaya isabet eden X-1şınlarının homojen dağılımı, X-ışınlarının dokulardaki saçılma ve soğurma yoluyla ışından çıkarılma derecesi ile değiştirilir.

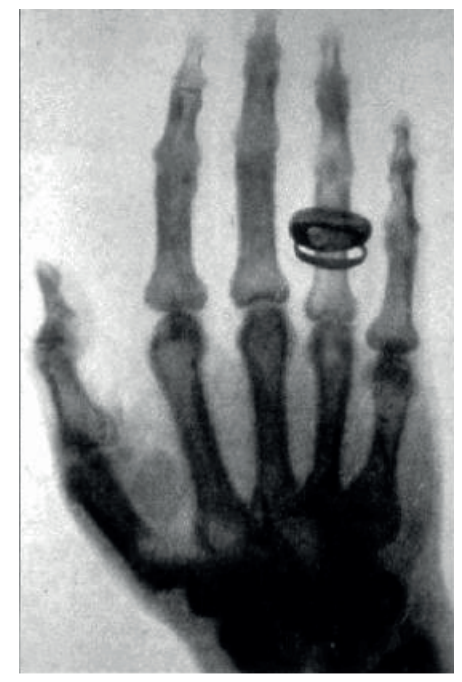

Şekil 1. Wilhelm Conrad Röntgen'in eşinin eline ait radyogram görüntüsü (https://www.winally.com)

Hastanın vücudunun içerisindeki yumuşak doku, kemik ve hava gibi özellikleri de birbirlerinden farklı oldukları için hastadan çıkan X-1şınlarının hetorojen dağılımda farklılık görülür. Radyogram görüntü bu röntgen dağılımının bir nevi bir resmi olarak ifade edilebilir. Radyografide kullanılan detektör, bir fotoğraf filmi olabilir. Radyogram görüntüler, akciğer kanseri, kemik kırılmalarında teşhis konulması, kardiyovasküler bozukluklar vb. alanlarda sıklıkla kullanılmakta ve çeşitli tıbbi endikasyonlarda da oldukça faydalıdır (Hou, Zhang, Wei, Guo ve Zhang, 2020).

\subsubsection{Floroskopi}

Floroskopi, zamana bağlı olarak bir dizi X-1şını görüntüsünün, aslında hastanın gerçek zamanlı bir X-1şını filminin sürekli bir şekilde elde edilmesidir. Floroskopi, gerçek zamanlı bir radyografi türüdür. Floroskopi kalp veya yemek borusu (özafugus) gibi anatomik hareketlerin röntgen filmlerinin yapımında kullanılmaktadır (Bushberg, Seibert, Leidholdt Jr, Boone ve Goldschmidt Jr, 2011).

Floroskopi ile X-ışınları tıpkı bir film gibi (zamana bağlı anlık görüntülerin serileştirilmesi) ekrana yansıtılmaktadır. Floroskopi işlemi esnasında vücudun görüntülenmek ve incelenmek istenen özel bir bölümü (organ) içinden sürekli bir 
biçimde X-1şını demetleri geçirilmektedir. Bu görüntüler daha sonra ilgili organın durum ve hareketinin uzmanlar tarafından değerlendirilmesi için ekrana yansıtılmaktadır (Larson, Lionhart, Roh ve Colglazier, 2018). Şekil 2'de bağırsak organının floroskopi yöntemi ile görüntülenmesi gösterilmektedir.

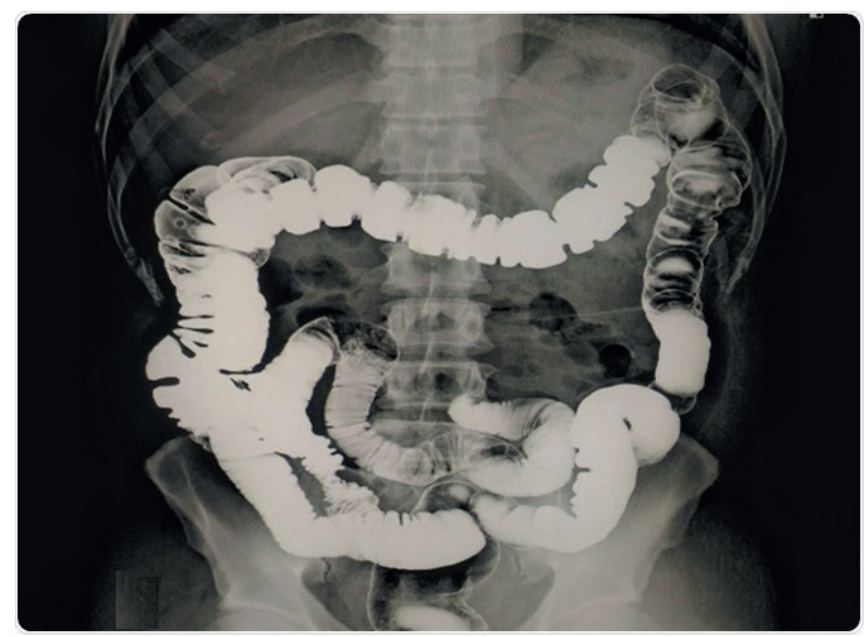

Şekil 2. Hastanın bağırsaklarının floroskopi ile görüntülenmesi (https://www.news-medical.net)

\subsubsection{Mamografi}

Mamografi, meme kanserinde kullanılan bir görüntüleme tekniği ve memenin bir radyografisidir. Mamografide, memedeki kontrastı vurgulamak için klasik radyografiden çok daha düşük seviyede X-1şını enerjisi kullanılmaktadır. Mamografi görüntüleme teknolojisinde kullanılan X-1şını ve detektör sistemleri sadece meme görüntülerine özel olarak tasarlanmış spesifik bir tekniktir. Mamografinin başlıca 2 kullanım amacı vardır. Bunlar, meme kanseri ile ilgili herhangi bir belirti göstermeyen kadınların kanser taramasında (tarama mamografisi) ve yumru varlığı gibi meme kanseri belirtisi gösteren kadınlarda teşhise (tanı tomografisi) yardımcı olması amacıyla kullanılmasıdır (Pisano ve Yaffe, 2005). Şekil 3’te meme kanseri tanısı için bir memenin mamografi yöntemi ile 2 boyutlu ve 3 boyutlu görüntülemesi gösterilmektedir.

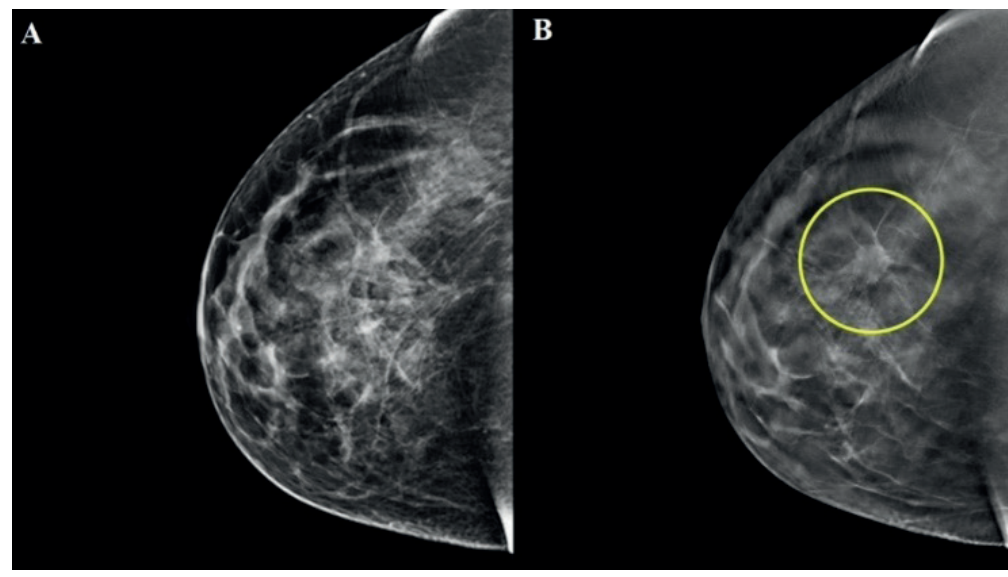

Şekil 3. Kanserli bir memeye ait Mamografik görüntü A) 2 Boyutlu, B) 3 Boyutlu (https://www.wakerad.com/)

Şekil 3’te gösterilen mamografi görüntüleri aynı hastaya ait aynı görüntülerdir. Sol tarafta gösterilen (A) görüntü, memeye ait 2 boyutlu mamografi görüntüsü ve sağ tarafta gösterilen (B) görüntüsü ise memeye ait 3 boyutlu mamografi görüntüsüdür. Şekil 3’te (B)'de yer alan 3 boyutlu mamografi görüntüsünde işaretlenen kısım, memedeki kanserli kısmı göstermektedir. 


\subsubsection{Bilgisayarlı tomografi}

BT, 1970’lerin başında kullanımı mümkün hâle gelen ve bir bilgisayar tarafından tıbbi görüntülemenin sağlandığı ilk yöntemdir. BT görüntüleri, X-1şınlarını vücuttan çok sayıda geçirmek suretiyle X-1şını tüpünü vücut etrafında döndürerek üretilmektedir. Röntgen kaynağının karşısında bir detektör dizisi iletim projeksiyon verilerini toplar. Bu biçimde toplanan çok sayıda veri noktası bir bilgisayar yardımı ile hastanın tomografik görüntülerine sentezlenir. Tomografi terimi iki kelimenin birleşimden oluşmaktadır. Tomo, dilim ve graphy ise resim olarak çevrilmektedir. Yani tomografi, bir dilimin bir resmini gösterir. BT, hastaya ait münferit doku levhalarının görüntülerini veren bir iletim tekniği olarak düşünülebilir. Günümüz teknolojisinin getirdiği yenilikler düşünüldüğünde BT’nin radyografiye göre üstünlüğü, ilgili anatominin 3 boyutlu dilimlerini gösterebilme, anatomik yapıların birbirlerinin üstüne binme sorununu ortadan kaldırma ve bu sayede doktorlara anatominin ayrıntılı ve kusursuz bir görünümünü sunma özelliğidir (Bushberg, Seibert, Leidholdt Jr, Boone ve Goldschmidt Jr, 2011; Szabo, 2004; Sluimer, Schilham, Prokop ve Van Ginneken, 2006).

BT teknolojisi, keşif cerrahisi ihtiyacını önemli ölçüde azaltarak tıp dünyasında önemli bir çığır açmıştır. Modern bir BT tarayıcısı 5 saniye gibi çok kısa bir zaman diliminde bir hastaya ait $50 \mathrm{~cm}$ uzunluğunda (800 görüntüye eşittir) ve 0.50 ila 0.62 mm kalınlığında tomografik görüntüleri elde edebilecek kapasiteye sahiptir (Szabo, 2004).

Şekil 4’te BT’nin farklı organlarda kullanımına ait bir örnek içeren, farklı organlara ait 6 farklı BT görüntüsü gösterilmektedir. Her bir görüntü bir harf ile temsil edilmektedir.

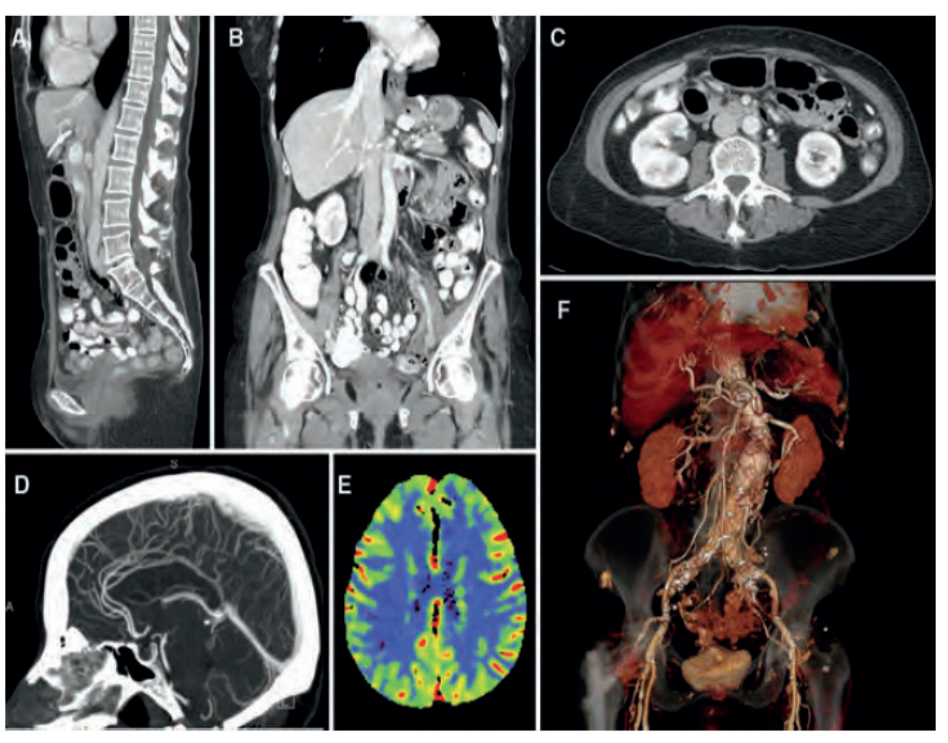

Şekil 4. Farklı organlara ait BT görüntüleri, Karın-pelvis BT Taraması Sonucunda Sagital (A), Koronal (B) ve Eksenel (C) görüntüler ile İyotlu Madde Enjeksiyonu Sonucunda Baş (D) Bölgesi, İnme (E) Değerlendirmesi Yapılan bir Hastaya ait Renk Kodlu Kan Hacim Haritası ve BT Verilerinden Görüntü İşleme ile Anatominin Sahte Renkli bir 3 Boyutlu Temsili (F) (Bushberg, Seibert, Leidholdt Jr, Boone ve Goldschmidt Jr, 2011)

\subsubsection{Manyetik rezonans görüntüleme}

MRG tekniğinde kullanılan tarayıcı cihazların yararlandıkları manyetik alan, dünyanın manyetik alanından yaklaşık 10.000 ila 60.000 kat daha güçlüdür. MRG tekniğinde ortam olarak genellikle protonun nükleer manyetik rezonansları tercih edilmektedir. Yani biyolojik dokularda oldukça fazla sayıda bulunan hidrojen atomunun çekirdeğini kullanırlar. Proton, manyetik bir momente sahip olup $1.5 \mathrm{~T}\left(1.5 \mathrm{~T}=10^{6}\right.$ Gauss) manyetik alana yerleştirildiği zaman proton ekseni etrafında ilerler ve radyo dalgası enerjisini saniyede yaklaşık 64 milyon devir rezonans frekansında (megahertz-MHz) emer (Huettel, Song ve McCarthy, 2004; Arslan, 2010). 
MRG'de görüntüleme prosedürünün başlatılması için hasta manyetik bir alan içerisine yerleştirilir. Daha sonra hastanın etrafına dizilmiş olan radyo antenleri aracıllğı ile radyo dalgaları üretilir. Vücutta bulunan protonlar radyo dalgalarını absorbe eder. Sonrasında ise hasta, bu radyo enerjisini dokunun manyetik özelliklerine bağlı olarak bir süre sonra tekrar salgılar. Hastadaki protonların yaydığı radyo dalgaları ise hastanın etrafına yerleştirilmiş olan antenler tarafından tespit edilir. Hastanın bulunduğu manyetik alanın gücü çok hafif bir şekilde değiştirilerek proton rezonans fonksiyonu değiştirilir. Bu, frekans ve manyetik alan kuvvetinin doğru orantılı olmasından kaynaklanmaktadır. MRI'da hastadan MRI cihazına gönderilen her bir sinyalin konumunun tespit edilebilmesi, geri dönen radyo dalgalarına ait frekans ve faz bilgileri ile mümkün olmaktadır. MRG’nin çok sık kullanılan çalışma yöntemlerinden biri "spin eko (spin echo)" görüntüleme olarak isimlendirilmektedir [(Bushberg, Seibert, Leidholdt Jr, Boone ve Goldschmidt Jr, 2011; Huettel, Song ve McCarthy, 2004; Buxton, 2009).

MRG, görüntüdeki her noktanın o noktaya karşllık gelen dokunun mikro manyetik özelliklerine bağlı bir dizi tomografik görüntü üretir. Beyinde yer alan yağ, gri ve beyaz madde, beyin omurilik sıvısı ve kanser gibi farklı doku türlerinin hepsi birbirlerinden farklı yerel manyetik özelliklere sahip olduklarından dolayı MRG ile üretilen görüntüler anatomik varyasyonlara karşı çok büyük bir hassasiyet gösterir. Bundan dolayı da görüntülerin kontrastı oldukça yüksektir. MRG, nörolojik görüntülemede (baş-omurga gibi), yaralanma ve sakatlanma gibi durumlarda diz görüntüleme gibi kas-iskelet yapılarında olağanüstü bir fayda göstermiştir (Huettel, Song ve McCarthy, 2004; Buxton, 2009).

MRG'de farklı nabız dizileri kullanılması sayesinde, MRG cihazı vücuttaki farklı doku özelliklerini ortaya çıarabilmekte ve doku türlerini de ayırt edebilmektedir. Bir futbol müsabakasında dizinden sakatlanan bir futbolcu düşünüldügünnde, dize ait MRG sayesinde futbolcunun çapraz bağlarının yırtılıp yırtılmadığı ya da ne kadar hasar aldığı tespit edilebilmektedir. Eğer hasar ciddi ise futbolcunun sahalardan ne kadar uzak kalması gerektiği bilinebilir ya da normal bir hastanın beyin MRG’si sayesinde beyindeki gri madde ile beyaz madde arasındaki farkın ölçülmesi mümkündür. Ayrıca; tümörler, kemik hasarları, damarlarda meydana gelen anormal durumlar için özel hassas görüntüler elde edilmesini sağlayan farklı nabız dizilerinin oluşturulması da MRG sayesinde gerçekleştirilebilmektedir (Huettel, Song ve McCarthy, 2004). Şekil 5’te MRI ile insan vücudunun görüntülenmiş farklı organları ve bunlara dair açıklamalar verilmektedir.

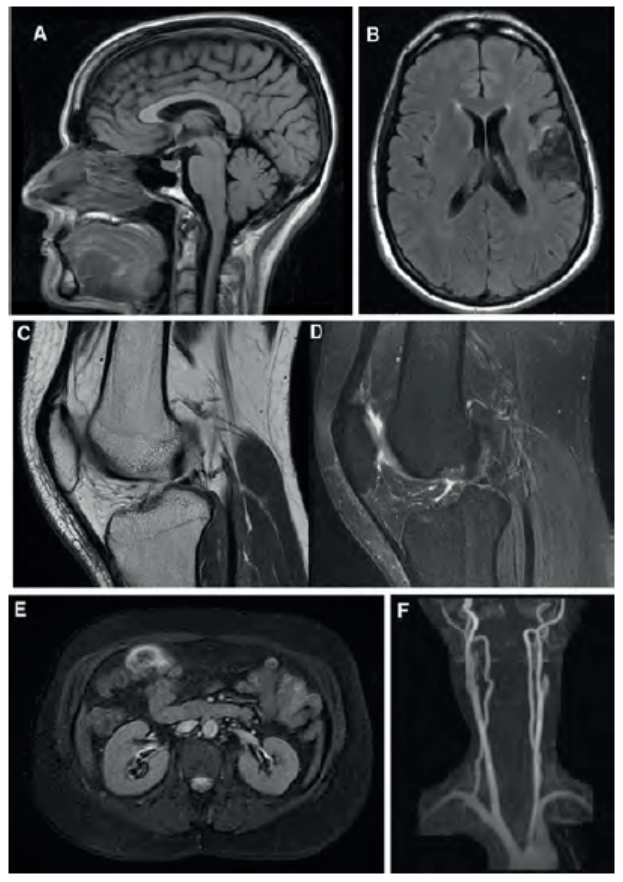

Şekil 5. MRI yöntemi ile görüntülenmiş organlar, (A) Beynin T1 ağılıklı kontrast; (B) beyin enfarktüsü bölgesinin FLAIR görüntüsü; (C) dizlerin T1 ağılıklı kontrast; (D) dizlerin T1 ağılıklı kontrast ile yağ doygunluğu; (E) maksimum yoğunluk projeksiyonu; (F) Gadolinyum kontrastlı karın görüntüsü (Bushberg, Seibert, Leidholdt Jr, Boone ve Goldschmidt Jr, 2011) 
Şekil 5'te verilen farklı organlara ait MRG görüntüleri bir harf ile temsil edilmekte ve açıklanmaktadır. Buna göre; (A) Beynin Sagittal T1 ağırlıklı kontrast görüntüsünü, (B) beyin enfarktüsü bölgesini gösteren eksenel sıvı ile zayıflatılmış inversiyon geri kazanımı (FLAIR) görüntüsünü, dizlerin sagital görüntüsü olarak; (C) T1 ağırlıklı kontrast ve (D) T1 ağırlıkl1 kontrast ile "yağ doygunluğu", (E) uçuş zamanı MR anjiyo gramının eksenel tomografik görüntülerinden üretilen maksimum yoğunluk projeksiyonunu, (F) ise Gadolinyum kontrastlı karın görüntüsüne karşılık gelmektedir.

MRG, vücut içerisindeki doku ya da organları radyo frekansı kullanarak görüntülemektedir. MRG tekniği radyasyon kullanmamakta ve yaymamaktadır.

\subsubsection{Ultrason}

Bir cisim yukarıdan aşağıya bir nesnenin üzerine düştü zaman etki basınç dalgalarının (ses) havada belirli bir mesafeden duyulacak şekilde yayılmasını sağlar. Yüksek frekanslı (ultra) ses formundaki mekanik enerji, hastaya ait anatomik görüntüleri oluşturmak için kullanılabilir. Kısa süreli bir ses darbesi, görüntülenen dokular ile doğrudan fiziksel temas halinde olan bir ultrason dönüştürücü aracılığı ile üretilmektedir. Ses dalgaları doku içerisine girerek vücutta yer alan iç yapılar sayesinde yansıtılır ve bu sayede yankı oluşturulur. Vücut içerisindeki iç yapılar ile yansıtılan ses dalgaları bir dönüştürücüye ulaşır. Dönüştürücü, yansıtılıp geri dönen sesi kaydeden bir mekanizmadır. Ultrason cihazının bu şekilde çalışan modu "darbe yankı görüntüleme (pulse echo imaging)" olarak adlandırılmaktadır (Leighton, 2007).

Ses dalgası, dikdörtgen şeklinde taranan bir alan oluşturmak için bir doğrusal dizi çok elemanlı dönüştürücü kullanılarak ya da bir sektör kullanılarak taranan alan üretmek için aşamalı bir dizi çok elemanlı dönüştürücü ile artan açılar yoluyla hastanın hizası üzerinde satır satır kaydırılır. Ultrason hatlarından alınan her bir yankı kaydedilir ve görüntülenmek istenen dokuların tomografik bir parçayı simgeleyen gri seviyede kodlanmış olan ses sinyalleri aracılığı ile bir parlaklık modu görüntüsünün elde edilmesi amacıyla kullanılmaktadır (Szabo, 2004; Shung, 2015).

Özellikle karın bölgesindeki organların yüzeyleri ve iç yapıları ultrason yöntemi ile çok güçlü bir şekilde yansıtılır ve görüntülenir. Ultrason, özellikle iyonlaştırıcı radyasyondan daha az zararlı olduğu için bu durum büyüyen bir fetüsün görüntülenmesinde ve gebe kadın (obstetrik) hastaların görüntülenmesinde Şekil 6'daki gibi kullanılmaktadır.

Şekil 6'da verilen dört farklı (A, B, C, D) görüntü arasında ilk üç görüntü (A, B, C) anne karnındaki bir bebeğe ait görüntülerdir. Zira bu görüntüler obstetrik hastalara ait görüntülerdir. Şekil 6'da verilen farklı görüntüler arasındaki son görüntü (D) ise ultrason görüntülemenin farklı bir versiyonu olan Doppler Ultrason görüntüsüdür.

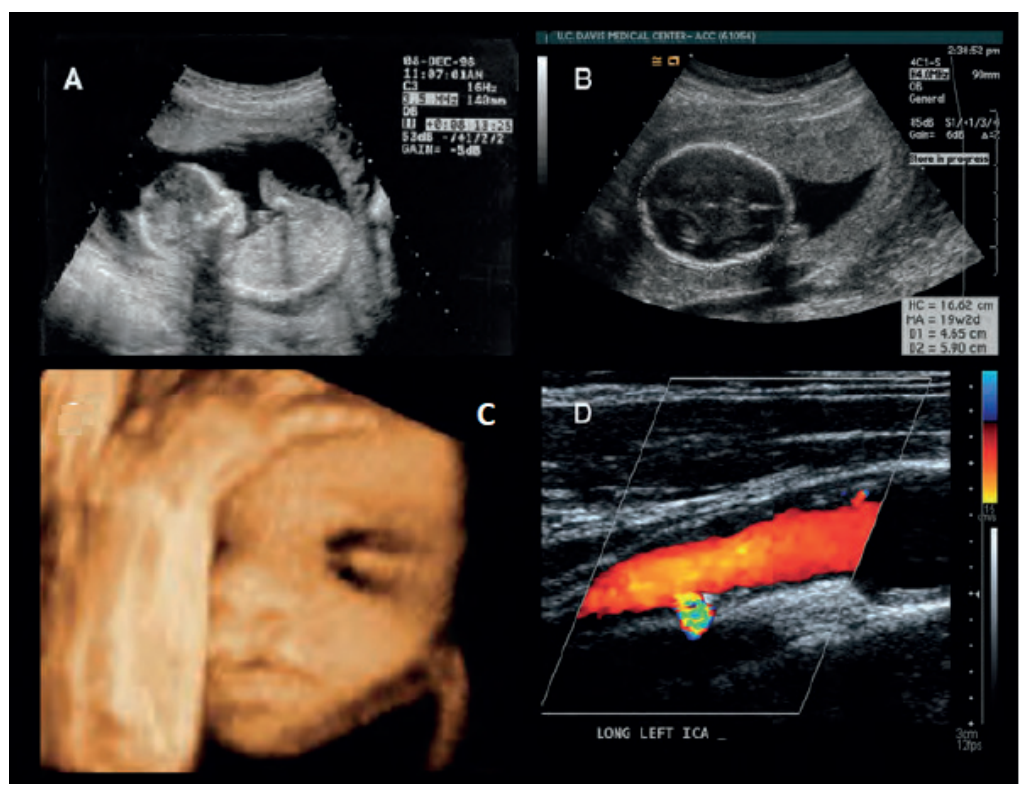

Şekil 6. Anne karnındaki bebeğin görüntüsü, (A) 2.5 aylık bir bebek; (B) bebek yaşı tahmini için bir fetüsün kesitsel beyin ultrason görüntüsü; (C) Ses görüntü verilerinin 3 boyutlu görüntüsü; (D) Doppler renk akış1 görüntüleme yöntemi ile vasküler (damar) değerlendirme (Bushberg, Seibert, Leidholdt Jr, Boone ve Goldschmidt Jr, 2011) 


\subsubsection{Doppler ultrason}

Doppler ultrason, Doppler etkisinin kullanıldığı özel ve geliştirilmiş bir ultrason çeşididir. Doppler etkisi açıklanırken genellikle çok bilindik bir fenomen kullanılmaktadır. Örneğin; çok hızlı bir şekilde yol alan ve istasyonda bekleyen birine yaklaşan bir tren düşünülsün. Tren istasyona yaklaştıkça çıkardığı sesin yükselmesi, istasyondan geçtikten sonra da bu sesin azalmasının sebebi yani sesin frekansında meydana gelen değişiklik, Doppler etkisinin bir sonucudur (Maulik ve Zalud, 2005).

Doppler etkisi, ses dalgasının kaynağı ile bunu gözlemleyen veya maruz kalan kişi arasında bir hareket gerçekleştiğinde, enerjinin bir dalga olarak iletiminde frekansta meydana gelen değişiklikleri kapsayan bir süreçtir (Maulik ve Zalud, 2005). Şekil 7'de Doppler etkisinin gerçek hayatta görülebileceği bir örnek görülmektedir.

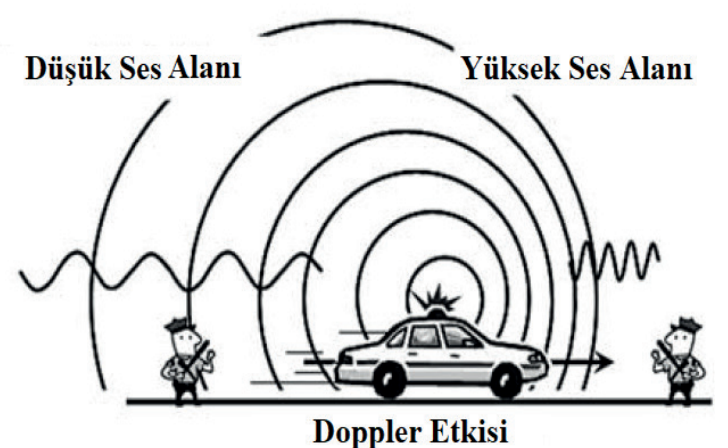

Şekil 7. Polis sireni ile Doppler etkisinin açıklanması (Maulik ve Zalud, 2005)

Şekil 7'de de görüldüğü gibi bir kaynak (polis sireni) ve iki gözlemci (polisler) vardır. Polis sireni Şekil 7'de sol tarafta bulunan polisten uzaklaşıp sağ taraftaki polise doğru yaklaşmaktadır. Bu sırada Doppler kayma sesi (siren sesi) ile sol taraftaki polis arasındaki dalga boyu artmıştır; yani frekans düşük seviyedir. Ancak sağ taraftaki polis ile siren arasındaki dalga boyu azalmıştır; frekans yüksek seviyededir. Siren sesi, hangi gözlemciye doğru hareket ederse, frekans yüksek seviyeye ulaşacaktır, arkasında bıraktığı gözlemci de ise frekans düşük seviyede olacaktır.

Normal bir ultrason ses dalgaları ile organların durumunu gösterir ve radyasyon yaymaz. Doppler Ultrasonun normal ultrasondan farkı ise damarlardaki kan akışını kontrol etmek amacıyla yüksek frekansa sahip ses dalgaları kullanmasıdır. Doppler Ultrason sayesinde kan hücreleri tespit edilebilmekte ve renkli bir şekilde görüntülenebilmektedir. Doppler Ultrason ile vücudun farklı organları ve dokuları görüntülenebilmektedir. Şekil 8'de Doppler Ultrason tekniği ile rahim ağzındaki kist bölgesindeki kan akışı görülmektedir.

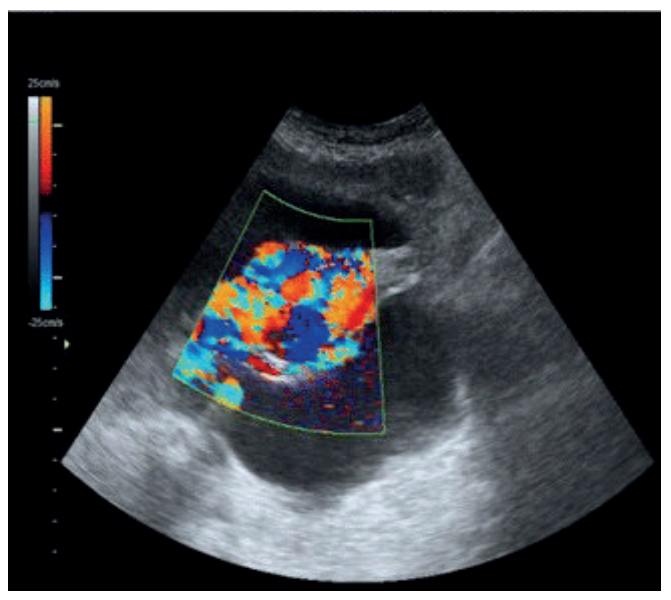

Şekil 8. Doppler Ultrason ile rahim ağzındaki kistlerde kan akışının görüntülenmesi (Mettler ve Guiberteau, 2012) 
Şekil 8'de verilen Doppler Ultrason tekniği ile görüntülenen bölgedeki farklı renkler, o bölgedeki kan akışı seviyeni göstermektedir.

\subsubsection{Nükleer tıp görüntüleme}

Nükleer tıp, radyoaktif izotop barındıran bir kimyasal ya da bir başka maddenin hastaya oral, enjeksiyon ya da havayı içine çekme (inhalasyon) yoluyla verilen radyoloji dalına verilen isimdir. Nükleer tıp görüntülemede (NTG) öncelikle materyal, hastanın fizyolojik durumuna göre dağıtılır. Burada materyal ile kastedilen, düşük seviyede bir radyoaktif maddedir. Bu, radyoaktif madde "ajan” olarak da isimlendirilmektedir. Ajan, incelenmek istenen dokuya ulaşır ve orada yerleşir. Ajanın yerleştiği dokunun görüntülenmesi için bir radyasyon dedektörü kullanılmaktadır. Daha sonra ajanın radyoaktif bozulma esnasında yayılan X-ışını ya da gama ışınlarından projeksiyon görüntüleri oluşturmak için bir radyasyon detektörü kullanılır. Nükleer tıp, emisyon görüntülerini üretir (Bushberg, Seibert, Leidholdt Jr, Boone ve Goldschmidt Jr, 2011).

NTG, bir fonksiyonel görüntüleme biçimidir. Nükleer tıp görüntüleri sadece hastaya ait anatomik yapı hakkında bilgi vermekle kalmaz bunun yanında hasta ile ilgili fizyolojik durumlarla alakalı bilgi de verir. Örnek verilecek olursa talyum, normal kalp kasında konsantre olma eğiliminde olmasına rağmen infarkte (dolaşım yetmezliği sebebiyle gerçekleşen doku ölümü) olan ya da iskemi (kan akışının azaldığı ya da kesildiği) olan bölgelerde talyum da konsantre olmayacaktır. Söz konusu bölgeler bir nükleer tıp görüntüsünde "soğuk noktalar (cold spots)" biçiminde görüntülenmektedir. Öte yandan nükleer tıp görüntüleri kalbin fonksiyonel durumunun görüntülenmesinde kullanılmaktadır. Tiroid dokusu iyot için büyük bir çekim (afinite) gücüne sahip olduğu için tiroid dokusuna radyoaktif iyot uygulandığında bir nükleer tıp görüntüsü olarak tiroid görüntülenebilmektedir. Eğer tiroid kanseri, hastada metastaz yapmışsa (yayılmışsa) işte o zaman nükleer tıp görüntülerinde yerlerini gösteren "sıcak noktalar (hot spots)" olabilir. Bu özellikleri düşünüldüğünde fonksiyonel görüntüleme nükleer tıbbın kalbi sayılabilmektedir (Mettler ve Guiberteau, 2012; Bushberg, Seibert, Leidholdt Jr, Boone ve Goldschmidt Jr, 2011).

\subsubsection{Nükleer tıp düzlemsel görüntüleme}

NTG yöntemi ile incelenmek istenen hastanın vücuduna bir ajan olarak radyoaktif madde enjekte edilir. Nükleer tıp düzlemsel görüntüleme (NTDG) sayesinde vücuda enjekte edilen bu ajanın ilgili doku ya da organ üzerindeki dağılımının görüntülenmesi düzlemsel (planar) bir X-1şını taraması gibi düşünülebilecek bir 2 boyutlu görüntü ile görülebilmektedir. NTDG genellikle tümör tespiti amacıyla kullanılmaktadır. NTDG’nin özelleştirilmiş bir kullanımı ise kemik ve yayılmacı (metastatik) tümörlerin tespitinde vücudun tamamının taranması ile sağlanmaktadır (Smith ve Webb, 2010).

NTDG yöntemi ile oluşturulan görüntüler birer projeksiyon görüntüleri olarak düşünülebilir. Çünkü görüntüde yer alan her bir nokta, hastanın üzerine yansıtılan bir çizgi boyunca radyo izotop aktivitesini temsil etmektedir. Düzlemsel nükleer görüntüler bir nevi 3 boyutlu radyo izotop dağılımına ait 2 boyutlu haritalar olarak düşünülebilir. Bu durum birçok bozukluğun değerlendirilmesinde yardımcı olmaktadır (Buck ve ark., 2008). Şekil 9'da NTDG ile kemik taraması görüntüleri görülmektedir. 


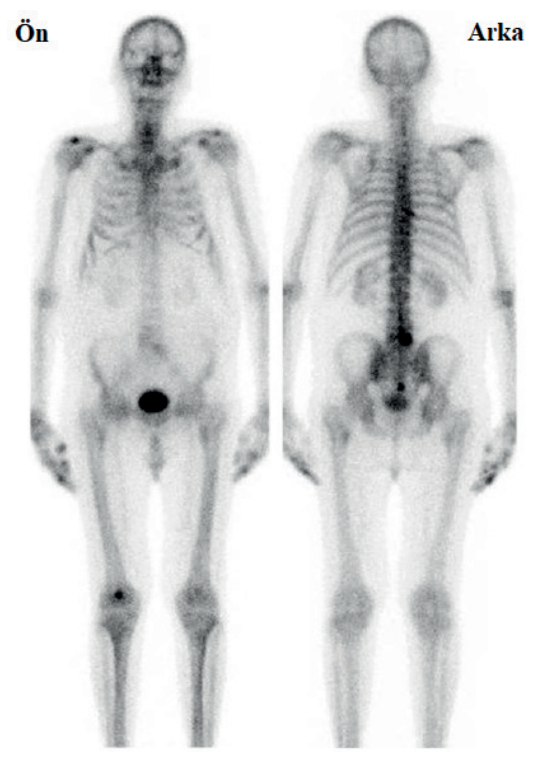

Şekil 9. NTDG ile kemik taraması (Buck ve ark., 2008)

Şekil 9'da kemik taraması için hastanın tüm vücudu NTDG yöntemi ile taranmaktadır. Elde edilen NTDG görüntüsü aynı hastaya ait olup önünden ve arkasından çekilmiştir.

\subsubsection{Tek foton emisyonlu bilgisayarlı tomografi}

Tek foton emisyonlu bilgisayarlı tomografi (SPECT), fizyolojik aktivitenin kesit ve 3 boyutlu görüntülerini elde etmeye yönelik düzlemsel sintigrafinin mantıksal yolu olarak tanımlanabilir. Böylelikle SPECT, BT ve MRI ile üretilen yapısal görüntüleri tamamlama imkânına sahip olur. "Anger” olarak adlandırılan bir kamera, herhangi bir anda radyoaktif bozulmaya ait projeksiyon görüntüsünü kameranın açısı boyunca çeker. Kamera döndüğünde projeksiyonlar BT'de kullanılan aynı rekonstrüksiyonun elde edilmesini sağlayan farklı açılardan toplanabilir. Tüm bunlara rağmen, BT ile SPECT karşılaştırıldığ 1 zaman SPECT çok daha yüksek bir gürültü seviyesine ve daha düşük bir uzaysal çözünürlüğe sahiptir (Haidekker, 2013).

X-1şınları ile görüntülemede bir organın vücudun iç yapılarının ne durumda olduğu yani nasıl göründüğü görüntülenirken, SPECT ile görüntülemede ise o organın nasıl çalıştığı görüntülenebilmektedir. Örneğin, beynin hangi bölgesinin aktif hangi bölgesinin daha az aktif olduğu SPECT ile görüntülenebilmektedir. Şekil 10'da beynin SPECT ile görüntülenmesi sayesinde Alzheimer Hastalığı teşhisinin yapılması görülmektedir.

Şekil 10'da SPECT yöntemi kullanılarak 3 farklı beyin görüntüsü gösterilmektedir. Soldan sağa doğru ilk beyin görüntüsü Normal, ikinci beyin görüntüsü Hafif Bilişsel Bozukluk ve üçüncü beyin görüntüsü ise Alzheimer Hastası olan üç farklı hastaya aittir. SPECT yöntemi sayesinde beynin sadece yapısı değil aynı zamanda nasıl çalıştığı da görüntülenebildiği için beyin görüntülenmesinde beyin ile ilgili hastalıklar da teşhis edilebilmektedir. 


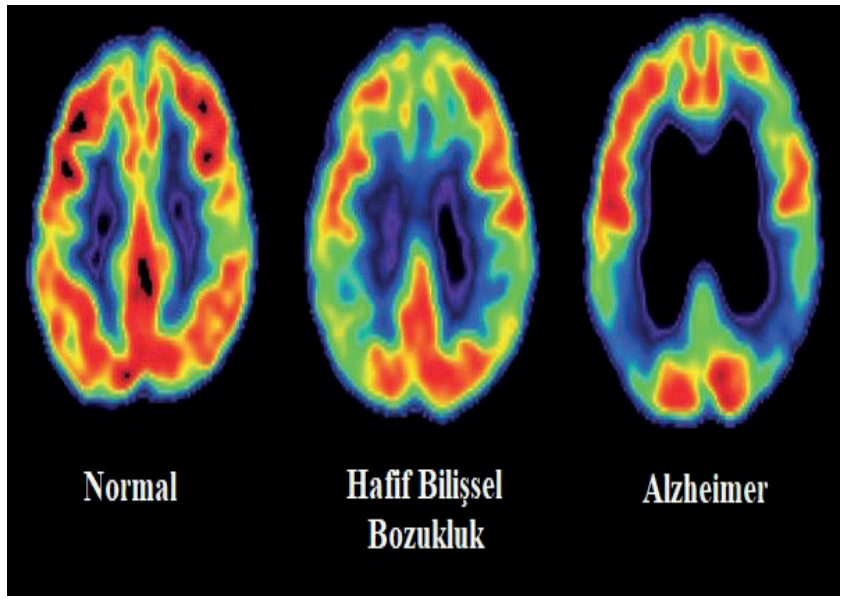

Şekil 10. SPECT ile beynin aktif bölgelerinin görüntülenmesi (https://www.pinterest.co.uk)

\subsubsection{Pozitron emisyon tomografi}

Pozitron emisyon tomografi (PET) görüntüleme, nükleer tıbbın neredeyse tüm etkisini ve rolünü değiştirecek şekilde geliştirilmiştir. Çünkü SPECT gibi geleneksel tek foton görüntülemeye ait tüm işlevleri daha iyi yapmanın yanında hızlı bir şekilde büyüyen teşhis uzmanlığı ve halkla ilişkiler özelliğinin etkisini de barındırmaktadır. PET yöntemi şu ana kadar en iyi radyo farmasötik kullanılan güçlü bir metabolik görüntüleme tekniğidir. Ayrıca PET, nükleer olmayan tıp klinisyenleri tarafından önemi takdir edilecek birçok çalışmada gösterdiği mükemmel kalitede görüntüler vermektedir (Bailey, Maisey, Townsend ve Valk, 2005).

PET, damar yolu ile vücuda enjekte edilen metabolik radyoaktif ajanların biriktiği normal veya patolojik dokuları görüntüleme imkânı sağlayan bir cihazdır. Şekerin bir türevi olan ve pozitron 1şıması yapabilen flor-18 ile işaretlenmiş “fdg” molekülü damar yolu ile enjekte edilmek suretiyle hastaya verilir (Buck ve ark., 2008). PET görüntülerinin işlenmesinde zayıflama düzeltmesi kullanılmaktadır. Zayıflama düzeltmesi ile beyin merkezinden salınan fotonların beyin çevresinden salınan fotonlardan daha fazla azaltılmasının önüne geçilmektedir (Lameka, Farwell ve Ichise, 2016). Şekil 11'de flor-18 ile işaretlenmiş ve zayıflama düzeltmesi uygulanan ve uygulanmayan bir beynin PET ile görüntülenmesi görülmektedir.

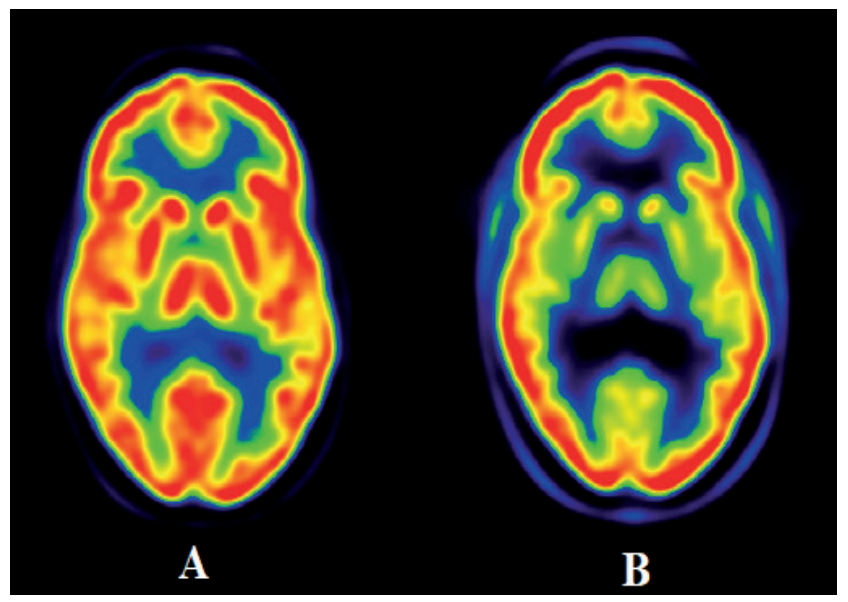

Şekil 11. Bir beynin PET ile görüntülenmesi, A) Zayıflama düzeltmesi uygulanan, B) Zayıflama düzeltmesi uygulanmayan (https://www.newyorker.com)

Şekil 11'de görüldüğü gibi zayıflama düzeltmesi uygulanmayan bir beynin PET görüntülenmesinde yoğunluğu yaklaşık \%50 oranında azalmakta olup bu durum uzmanların ve geliştirilen sistemlerin daha başarılı değerlendirmesinde yararlı olmaktadir. 


\section{TIBBİ GÖRÜNTÜLEMEDE YAPAY ZEKÂ KULLANIMI}

Son yıllarda özellikle derin öğrenmenin popülerliği ve gelişimi sayesinde yapay zekâ teknolojisinde çok ciddi ilerlemeler görülmektedir. Yapay Zekâ teknolojisindeki gelişmelerden faydalanan konulardan biri de tıbbi görüntülemedir. Tıbbi görüntüleme alanında radyolojide görülen gelişmeler ve yapay zekânın bu alandaki kullanımından elde edilen başarılı sonuçlar, bu alandaki radyolog ve teknisyenlerin bu teknolojiyi ne denli benimsediklerinin iyi bir örneğidir (The, 2018).

2019 yılı itibari ile yapay zekâ destekli birçok sağlık çalışması araştırma ve geliştirme aşamasında olup, tıbbi görüntüleme alanında yapay zekâ kullanımı ile ilgili çalışmaların klinik değeri büyük oranda spekülasyona açık ve hâlâ çok güçlü klinik bulgularla desteklenmemektedir (The, 2018; Morra, Delsanto ve Correale, 2019).

Tıbbi görüntülemede yapay zekâ tabanlı uygulamalar geliştirmenin en zorlu yanlarından ve hatta en büyük dezavantajlarından biri veri kümesine erişim ve veri kalitesinin istenen düzeyde olmasıdır. Son yıllarda tıbbi görüntülemenin tamamen dijitalleştirilmesinin beraberinde getirdiği sorunlardan biridir veriye erişmek. Başarılı sonuç veren bir yapay zekâ modelinin ortaya konulması için eğitim ve test verileri olmazsa olmazlar arasındadır. Bu nedenle bu sorunlar yakın gelecekte acilen çözüm bulunması gereken en önemli konuyu teşkil etmektedir yani veriye erişim konusu (Morra, Delsanto ve Correale, 2019).

Veriye erişim sorununun kısmen çözülmesi için tıbbi görüntüleme alanında yapay zekâ kullanımının geliştirilmesini amaçlayan araştırmacılar tarafından önerilen yollardan biri de, yapay zekâ içerisindeki öğrenme stratejilerinin geliştirilmesi ve veri artırma (data augmentation), transfer öğrenme (transfer learning) ve aktif öğrenme (active learning) gibi konulara yatırım yapılarak veri bağımlılı̆̆ının en aza indirgenmesidir (Sahiner ve ark., 2019).

Yine veriye erişim ile ilgili sorunların çözümü noktasında önerilen bir başka yol daha mevcuttur. $\mathrm{Bu}$ da, kişisel verilere erişimin düzenlenmesine yönelik yeni bir etik anlayışıdır. Kişisel verilere erişimde mahremiyet kuralarının ihlal edilmemesi sadece tıbbi alanda araştırma yapan kişi ya da toplulukların değil aynı zamanda teknoloji devi şirketlerin de karşılaştığ ve hatta yargılandığı bir sorundur (Hutton ve Henderson, 2017). Bu sorun, özellikle Avrupa'daki araştırmacıların, Çin gibi kişisel verilere erişimde daha geniş haklar tanıyan ülkelerin bu alanda yapacakları çalışmalar ile büyük bir avantaj sağlayacaklarını düşünmelerine neden olmaktadır (https://www.wired.com/; https://www.wsj.com/). Veriye erişimdeki mahremiyet ihlallerinin önüne geçilmesi ve tıbbi görüntüleme alanında yapılacak çalışmaların da sekteye uğramaması için Avrupa'da biyo bankalar konusunda bir farkındalık gelişmeye başlamıştır (ESR, 2015; Neri ve Regge, 2017).

Son yıllarda özellikle derin öğrenme alanında bilgisayarlı görü konusu sayesinde farklı sektörlerin yapay zekâya olan ilgisi bir başka boyuta ulaşmıştır. Tıp bilimi kendi içerisinde birçok disiplini barındırmaktadır. Hasta psikolojisini düşünme, mahremiyeti ihlal etmeme, empati kurma gibi etik ve insani konular elbette ki otomatikleştirilemez. Böylesi durumlar insanidir. Yapay zekânın tıbbi görüntülemede kullanımı konusu sadece doktorlara ve diğer sağlık personellerine ve bu alandaki uzmanlara yardımcı olabilecek uygulamalar geliştirilmesinden ibarettir. Bu durum hem sağlık çalışanlarının hem de hastaların menfaatine olacaktır. Tıbbi görüntülerin yorumlanması ve bu doğrultuda konulacak bir teşhisin en kısa sürede ve büyük bir doğruluk ile konulması, hasta durumunun takibi vb. konularda yapay zekâ sayesinde hem zamandan tasarruf edilecek, hem maddi kaynaklar en az düzeyde kullanılacak hem de yapılacak çalışmalara olan güven ve dolayısı ile yatırım artacaktır (Ranschaert, Morozov ve Algra, 2019).

\subsection{Bilgisayar Destekli Tanı Sistemleri}

Medikal görüntülerin manuel olarak analiz edilmesi, değerlendirilmesi ve sınıflandırılması gibi işlemler hem maliyet hem de zaman açısından oldukça büyük bir yük teşkil etmektedir. Özellikle böylesine hassas görüntüler değerlendirileceği zaman analiz eden kişi ya da kişiler tarafından önerilen yanlış bir yorum ya da değerlendirme, hasta açısından hayati derecede bir hataya sebebiyet verebilmektedir. Ayrıca, görüntülemeyle ilgili tıbbi bakım maliyetleri de çok hızlı bir şekilde artmaktadır (Cheng, Cai, Chen, Hu ve Lou, 2003). Bu sebeplerden dolayı yeni teşhis yöntemlerine ihtiyaç duyulmaktadır. Günümüzde bilgisayar destekli tanı (CAD), tanısal radyoloji ve tıbbi görüntülemede çok sayıda önemli araştırma konularından biridir (Murino, Puppo, Sona, Cristani ve Sansone, 2015; Al-shamasneh ve Obaidellah, 2017). 
CAD yaklaşımı, doktorların muayene süresini ve maliyetini en aza indirirken gereksiz biyopsi prosedürlerinden kaçınmanın haricinde hastalıkları daha yüksek bir verimlilik ile teşhis etmelerinde büyük fayda sağlamaktadır. CAD, günümüzde BT, MRI, X-Işını ya da mamogram görüntülerinin uygulanması ile birincil kanser teşhisi için çok daha uygun bir yöntemdir (Doi, 2007; Al-shamasneh ve Obaidellah, 2017). CAD, medikal giriş görüntüleri ile uzman (radyolog) arasında bir ara katman görevi görmektedir. Burada dikkat edilmesi gereken nokta CAD çıktısının bir sonuç olarak kabul edilemeyeceğidir. Fakat elde edilen çıktı, ilgili alanda yapılan ek testler için referans olarak kullanılabilir (Al-shamasneh ve Obaidellah, 2017).

CAD, kanserin erken ve daha kesin tespitinde doktorlara yardımcı olmaktadır. CAD sistemi yapay zekâ, dijital görüntü işleme, tıbbi bilgi işleme, görüntü analizi ve örüntü tanıma gibi alanlarda birden fazla bilim dalı ile ilişkili olarak geliştirilebilmektedir (Murino, Puppo, Sona, Cristani ve Sansone, 2015; El-Baz ve ark., 2013).

CAD sistemi çoğunlukla beyin, akciğer, meme ve başka kanser türleri için faydalıdır. CAD günümüz teknolojisi sayesinde oldukça ilerlemiş ve yüksek düzeyde doğruluğa ulaşmıştır. CAD sisteminin başlıca parametreleri de özgüllük (specifity), hassasiyet (sensitivity) ve mutlak tespit oranını (absolute detection rate) içermektedir (Al-shamasneh ve Obaidellah, 2017).

Şekil 12’de akciğer kanseri için BT görüntülerinin giriş olarak kullanıldığı bir CAD sistemi yapısı verilmektedir.

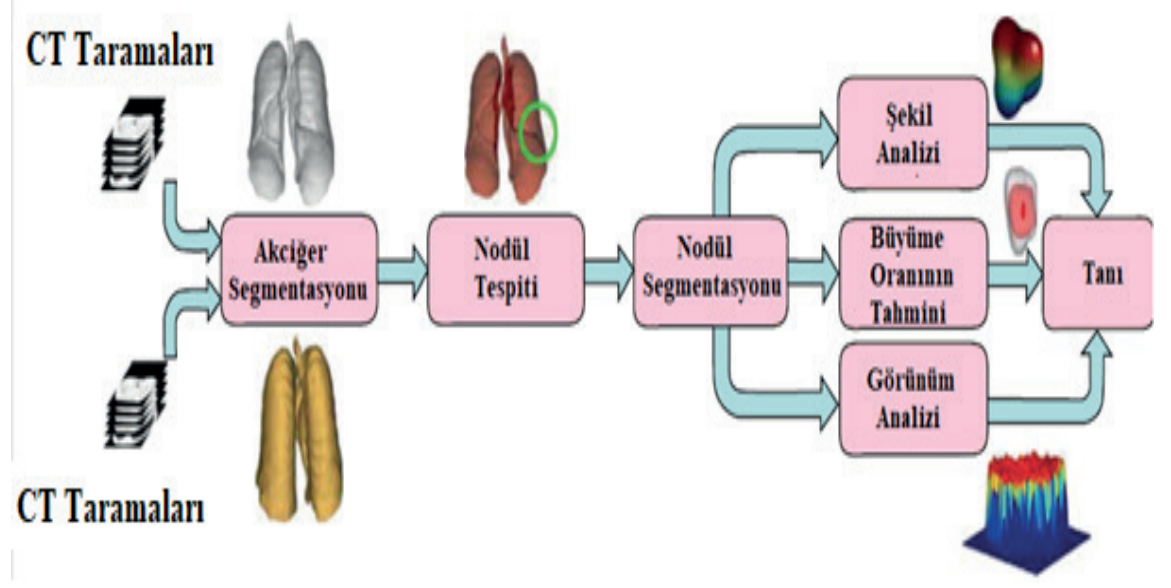

Şekil 12. Akciğer kanseri için CAD sistemi diyagramı (El-Baz ve ark., 2013)

Şekil 12'de görüldüğü gibi bir CAD sisteminin girişi, uygun bir yöntem kullanılarak elde edilen tıbbi görüntülerdir. Akciğer nodüllerinin arama alanını azaltmak için bir akciğer bölütlenmesi (segmentasyonu) adımı kullanılır. Nodül tespiti, akciğer nodüllerinin yerlerini belirlemek için kullanılır. Tespit edilen nodüller segmentlere ayrılır. Daha sonra hacim, şekil ve görünüm özellikleri gibi bir öznitelik seti çıkarılır ve tanı için kullanılır (El-Baz ve Suri, 2019). Öznitelik verilerinin tanı için kullanılmasında yapay zekâ tekniklerinden sıklıkla yararlanılmaktadır.

\section{LITERATÜR ÇALIŞMASI}

Literatür içerisinde Tıbbi görüntüleme ve yapay zekâ teknolojilerini birlikte ele alan, yapay zekânın tıbbi görüntülemede kullanımını inceleyen bir makale çalışması bulunmamaktadır. Var olan çalışmaların hemen hepsi, bir tıbbi görüntüleme teknolojisinden elde edilen tıbbi bir görüntünün analizini yapan çalışmalardır. Bu çalışmanın en özgün yanı, yapay zekâ ve onun alt disiplinlerini açıklayıp ve aralarındaki farkı ortaya koyması, farklı enerji türlerini kullanan tıbbi görüntüleme teknolojilerini bir arada vermesi ve en önemlisi tıbbi görüntülemede yapay zekâ kullanımının mevcut durumu hakkında açık ve kapsamlı bilgiler vererek tüm bunları kavramsal olarak ortaya koymasıdır.

Tıbbi görüntülemede yapay zekânın kullanımına dair birçok çalışma bulunmakta olup, bu çalışmalar hastalıklara ait tanı konmasında ve uzmanlara yardımcı bilgiler vermeleri açısından önemlidir. Bunun yanında ileride yapılabilecek diğer çalışmalara da ışık tutmaktadırlar. Güncel çalışmalara ilişkin problem tanımları, yöntemler ve elde edilen sonuçlar Tablo 1'de verilmiştir. 
Tablo 1

Tıbbi görüntülemede yapay zekâ kullanımı ile ilgili yapılmış çalışmalar

\begin{tabular}{|c|c|c|c|c|}
\hline Yazar(lar) & $\begin{array}{c}\text { Görüntüleme } \\
\text { Tekniği }\end{array}$ & Araştırma Konusu & Yöntem* & Sonuç \\
\hline Talo (2019) & Radyografi & $\begin{array}{l}\text { Akciğer radyografi görüntüleri ile } \\
\text { pnömoni hastalığının teşhisi }\end{array}$ & $\begin{array}{c}\text { Transfer Öğrenme ile } \\
\text { ResNET-152 Evrişimsel } \\
\text { Sinir Ağı }\end{array}$ & Doğruluk (Accuracy) $=0.974$ \\
\hline $\begin{array}{l}\text { Chow ve ark. } \\
(2020)\end{array}$ & Floroskopi & $\begin{array}{l}\text { Cerrahi hassasiyeti artırmak için } \\
\text { tek ve çift düzlemli floroskopi } \\
\text { görüntülerinin kendi kendini } \\
\text { kalibre etmesi }\end{array}$ & $\begin{array}{l}\text { Yumuşatılmış } \\
\text { k-En Yakın Komşu } \\
\text { Regresyonu }\end{array}$ & $\begin{array}{c}\text { Floroskopi görüntülerine ait } \\
3 \text { boyutlu haritalama hatası } \% 94.2 \text { ve } \% 95.7 \\
\text { oranında azaltılmıştır. }\end{array}$ \\
\hline Tiryaki (2020) & Mamografi & $\begin{array}{c}\text { Kitleli ve kalsifikasyonlu } \\
\text { mamografi görüntülerinin } \\
\text { sinıflandırılması }\end{array}$ & Yapay Sinir Ağları & Doğruluk Oranı $=\% 85.74$ \\
\hline Budak (2019) & BT & $\begin{array}{l}\text { BT görüntülerinde karaciğer } \\
\text { bölgesinin bölütlenmesi }\end{array}$ & SegNet & $\begin{array}{l}\text { Bölütleme ortalama } \\
\text { başarıs1 }=67.41\end{array}$ \\
\hline Sarhan (2020) & MRI & $\begin{array}{c}\text { Beyin tümörlerinin } \\
\text { sınıflandırılması için yeni bir } \\
\text { Bilgisayar Destekli Tespit tekniği }\end{array}$ & $\begin{array}{l}\text { Dalgacık tabanlı } \\
\text { Evrişimli Sinir Ağ } 1 \\
\text { (WCNN) }\end{array}$ & $\begin{array}{l}\text { Doğruluk }=\% 99.3 \\
\text { Duyarlılık }=\% 97.4 \\
\text { Özgüllük }=\% 95.5\end{array}$ \\
\hline $\begin{array}{l}\text { Vakanski ve } \\
\text { ark. }(2020)\end{array}$ & Ultrason & $\begin{array}{l}\text { Meme kanserinin teşhisinde } \\
\text { ultrason görüntülerinin görsel } \\
\text { belirginliğinin artırılması }\end{array}$ & $\begin{array}{l}\text { Dikkat Blokları } \\
\text { eklenmiş U-Net Modeli } \\
\text { (U-NET-SA-C) }\end{array}$ & $\begin{array}{c}\text { Zar Benzerlik Katsayısı (DSC) }=\% 90.5 \\
\text { Doğruluk }=\% 95.7\end{array}$ \\
\hline $\begin{array}{l}\text { Shia ve Chen } \\
(2020)\end{array}$ & Doppler Ultrason & $\begin{array}{l}\text { İyi huylu ve kötü huylu tümör } \\
\text { sinıflandırması }\end{array}$ & $\begin{array}{l}\text { Derin Öğrenme (Deep } \\
\text { Learning) }\end{array}$ & $\begin{array}{l}\text { Duyarlılık }=\% 77.08 \\
\text { Özgüllük }=\% 91.07\end{array}$ \\
\hline $\begin{array}{l}\text { Cai ve ark. } \\
(2018)\end{array}$ & NTDG & $\begin{array}{c}\text { Üst üste binmiş olan NTDG } \\
\text { görüntülerinin tek çekim } \\
\text { haritalaması }\end{array}$ & $\begin{array}{c}\text { ResNet tabanlı uçtan } \\
\text { uca derin Evrişimli Sinir } \\
\text { Ağ } 1\end{array}$ & $\begin{array}{l}\text { Önerilen modelde geleneksel yöntemlere göre } \\
\text { daha başarılı haritalama sonucu elde edilmiştir. }\end{array}$ \\
\hline $\begin{array}{l}\text { Shi ve ark. } \\
(2020)\end{array}$ & SPECT & $\begin{array}{c}\text { Derin Öğrenme yöntemleri ile } \\
\text { zayıflama haritalarının tahmin } \\
\text { edilerek SPECT görüntülerinin } \\
\text { doğruluğunun artırılması }\end{array}$ & $\begin{array}{l}\text { Derin Evrişimsel Sinir } \\
\text { A ğ } 1\end{array}$ & $\begin{array}{c}\text { Model uygulanmadan önce; } \\
\text { SPECT görüntüleri arasındaki Normalleştirilmiş } \\
\text { Ortalama Mutlak Hata (NMAE) }=\% 3.60 \text { iken, } \\
\text { Model uygulandıktan sora; } \\
\text { SPECT görüntüleri arasındaki Normalleştirilmiş } \\
\text { Ortalama Mutlak Hata (NMAE) }=\% 0.26 \text { olarak } \\
\text { bulunmuştur. }\end{array}$ \\
\hline $\begin{array}{l}\text { Dong ve ark. } \\
(2020)\end{array}$ & PET & $\begin{array}{l}\text { PET görüntülemede zayıflama } \\
\text { düzeltmesi için Derin Ögrrenme } \\
\text { tabanlı model geliştirilmesi }\end{array}$ & $\begin{array}{l}3 \text { Boyutlu yama tabanlı } \\
\text { Döngü Bağıntılı } \\
\text { Çekişmeli Üretici Ağlar } \\
\text { (CycleGAN) }\end{array}$ & $\begin{array}{l}\text { Orijinal PET görüntüleri ile modelin uygulandığ1 } \\
\text { PET görüntüleri kıyaslandığında ölçülen yoğunluk } \\
\text { değişiklikleri \%3’ten daha düşük bir oranda } \\
\text { farklılık gösterdiği görüşmüştür. }\end{array}$ \\
\hline
\end{tabular}

*: Tablo 1'de verilen yöntemler, 4.1. Yöntemler bölümünde kısa ve genel bir şekilde açıklanmaktadır.

\subsection{Yöntemler}

Çalı̧̧manın bu bölümünde Tablo 1'de verilen yöntemlerin klasik mimarileri açıklanmaktadır. Bu sebeple, ilk olarak derin öğrenme alanında bilgisayarlı görünün temeli olan Evrişimli Sinir Ağları anlatılmaktadır. Bilgisayarlı görü alanında Evrişimli Sinir Ağları'ndan sonra geliştirilen tüm ağlar ondan esinlendiği için bu ağların en temel katmanları açılanmaktadır.

\subsubsection{Evrişimli Sinir Ağları (Convolutional Neural Network)}

Derin öğrenmenin bir alt dalı olan Evrişimli Sinir Ağları (LeCun, Bottou, Bengio ve Haffner, 1998), özellikle çek-senet ve sokak tabelaları üzerindeki rakamların tanınması amacıyla oluşturulmuş bir ağdır. Genel itibari ile bir Evrişimli Sinir Ağı (ESA) 4 katmandan oluşur. Bunlar: Evrişim katmanı, ortaklama katmanı ve düzleştirme katmanı ve tam bağlantı katmandır.

Evrişim Katmanı (Convolutional Layer), bilgisayarlar için görüntüler, satır ve sütunlardan oluşan matrisler ile ifade edilir. Görüntünün en küçük birimi ise piksel olarak ifade edilir (Gonzalez ve Rafael, 2018). ESA'da bir görüntünün sınıflandırma, bölütleme veya başka bir işlem için kullanılması için filtre matrisi denilen öznitelik çıkarım matrislerinden faydalanılır. Filtre matrisi, resim (görüntü matrisi) üzerinde satır satır (stride) kaydırılarak görüntü matrisinden öznitelikler çıkarır. Bu işlem aslında basit bir çarpma ve toplama işlemi olarak düşünülebilir. Şekil 13’te evrişim işleminin nasıl gerçekleştiği gösterilmektedir. 
Görüntü Matrisi

\begin{tabular}{|l|l|l|}
\hline 1 & 2 & 3 \\
\hline 4 & 5 & 6 \\
\hline 7 & 8 & 9 \\
\hline
\end{tabular}

Filtre Matrisi

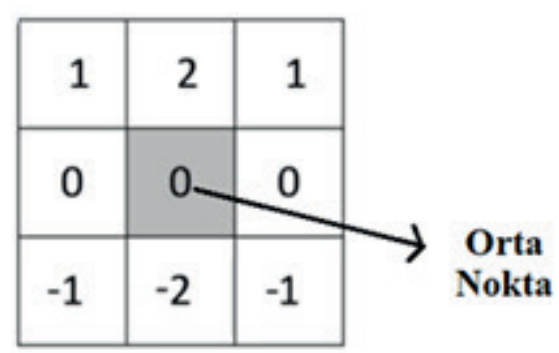

Evrisim İslemi

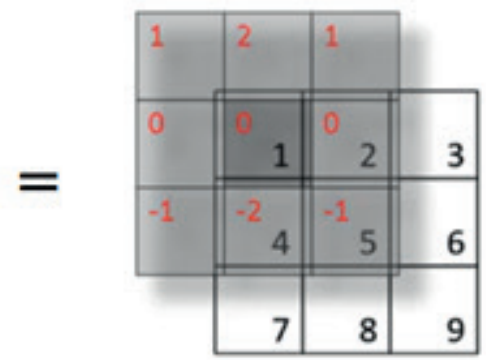

\section{Evrișim}

Şekil 13. Filtre matrisinin orta noktasının görüntü matrisinin ilk pikseli üzerine yerleştirilerek evrişim işleminin başlatılması

Şekil 13’te gösterilen evrişim işleminin sonucunda elde edilen yeni görüntü matrisi Şekil 14’te gösterilmektedir.

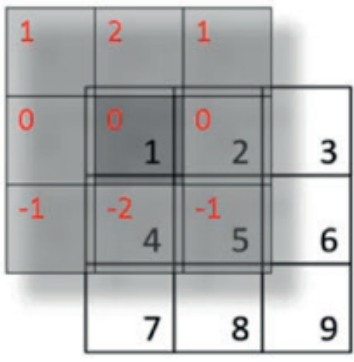

(a)

$$
\begin{aligned}
= & 0 \cdot 1+0 \cdot 2+0 \cdot 1 \\
& +0 \cdot 0+1 \cdot 0+2 \cdot 0 \\
& +0 \cdot(-1)+4 \cdot(-2)+5 \cdot(-1)
\end{aligned}
$$$$
=-13
$$

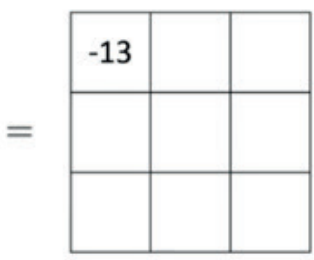

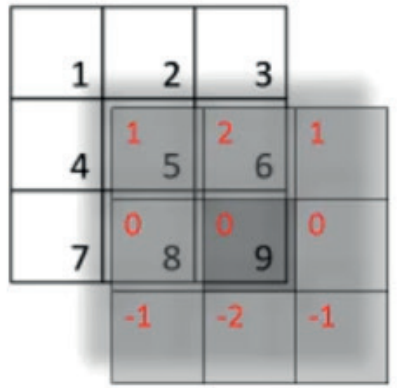

(b)

$$
\begin{aligned}
= & 5 \cdot 1+6 \cdot 2+0 \cdot 1 \\
& +8 \cdot 0+9 \cdot 0+0 \cdot 0 \\
& +0 \cdot(-1)+0 \cdot(-2)+0 \cdot(-1) \\
= & 17
\end{aligned}
$$

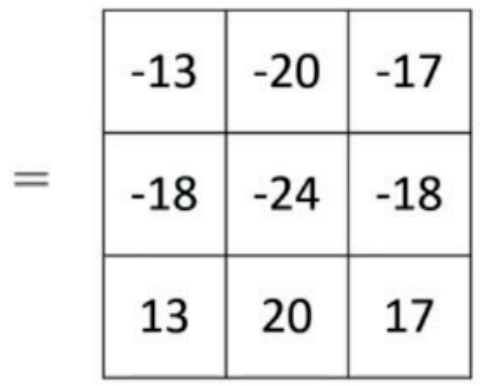

(c)

Şekil 14. Görüntü matrisinin; (a) ilk değerinden başlanarak, (b) son değerine ulaşıncaya kadar filtre matrisi ile evrişim işlemine girmesi sonucunda oluşan (c) yeni görüntü matrisi.

Ortaklama Katmanı (Pooling Layer), klasik ESA'da alt örnekleme (subsampling) olarak ifade edilmektedir (LeCun, Bottou, Bengio ve Haffner, 1998). Ortaklama katmanı, görüntünün boyutunu azaltmak için kullanılır. 2 tür ortaklama vardır: ortalama ortaklama (avarage pooling) ve maksimum ortaklama (maximum pooling). Ortalama ortaklama, giriş görüntüsünde $n$ adet pikseli toplayıp $n$ sayısına böler. Maksimum ortaklama, görüntü matrisi üzerindeki en yüksek piksel değerini baz alır. Şekil 15 ’te ortalama ortaklama ve maksimum ortaklama gösterilmektedir. 


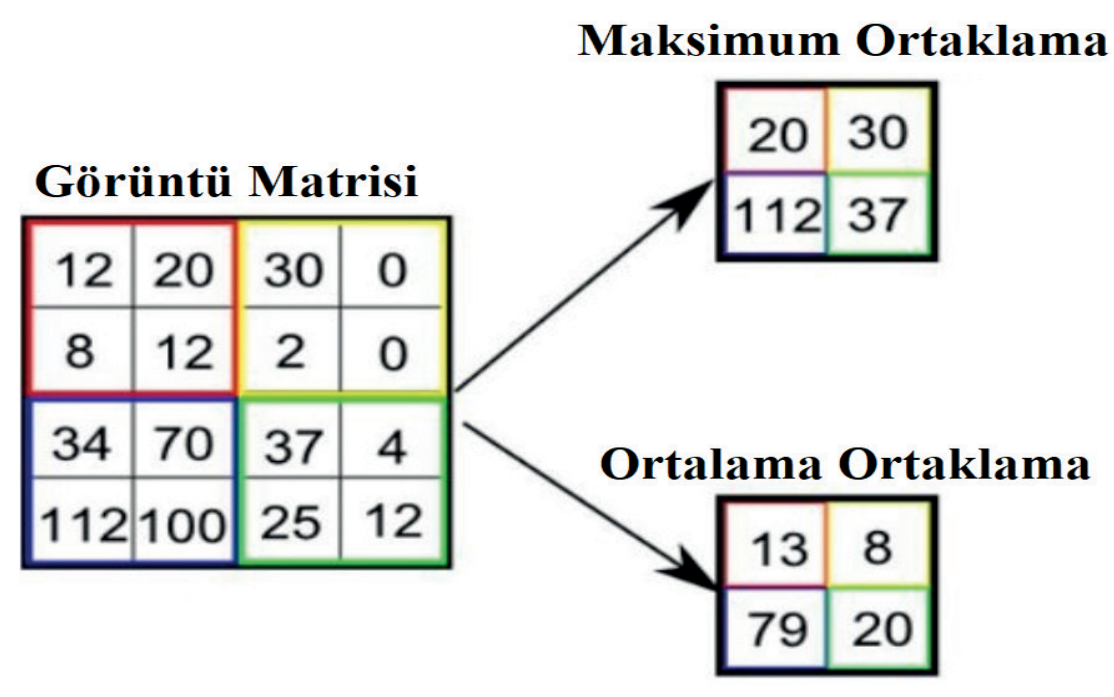

Şekil 15. Görüntü matrisinin maksimum ortaklama/ortalama ortaklama ile boyutunun azaltılması (https:// towardsdatascience.com/)

Şekil 15'te gösterilen örnekte 4x4'lük 16 pikselden oluşan 2 boyutlu bir görüntü matrisi, ortaklama işlemi sonucunda 2x2'lik 4 piksellik bir görüntü haline getirilmiştir.

Düzleştirme Katmanı (Flattening Layer), ESA'daki bu katmanın görevi, görüntüyü yapay sinir ağına (YSA) iletmek için vektör (tek sütunluk dizi) haline getirmektir. Şekil 16'da tam bağlantı katmanında vektör haline getirilen bir görüntü matrisi gösterilmektedir.

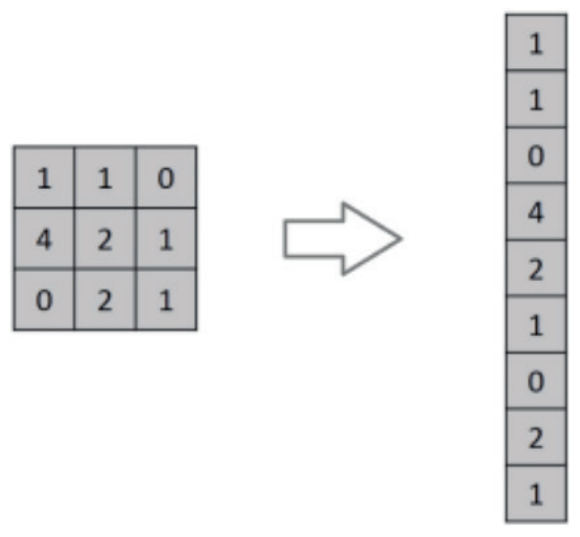

Şekil 16. Düzleştirme katmanı sayesinde 3x3'lük bir görüntünün 1x9'luk bir vektöre dönüştürülmesi

Tam Bağlantı Katmanı (Fully Connected Layer), ESA’nın son katmanıdır ve düzleştirme katmanında vektör haline getirilen verileri YSA ile öğrenme işleminin gerçekleşmesini sağlar.

\subsubsection{Artık Ağlar (Residual Networks)}

Derin öğrenme, büyük verilerle uğraşmaktadır. Bilgisayarlı görü alanında yapılan çalışmalarda genellikle önceden eğitilmiş ağlar (pre-trained) kullanılmaktadır. Bunun sebebi, bir problemin çözümünde yeniden bir ağ kurmak yerine, benzer bir problem için oluşturulmuş ve kullanılmış bir ağın transfer edilerek kullanılması hem zaman açısından hem de maliyet açısından oldukça kazançlı bir fikirdir. Transfer öğrenme, bu tür sorunlar için çok iyi bir seçenektir.

Artık ağlar (ResNet), 2015 yılında düzenlenen "The ImageNet Large Scale Visual Recognition Challenge (ILSVRC)" yarışmasında \%3.57 hata oranı ve \%95.51'lik başarı oranı ile birinciliği kazanan bir Derin Nöral Ağ (Deep Neural Network) mimarisidir (He, Zhang, Ren ve Sun, 2016). 
Özellikle ESA'ların gelişmesi ile ağlar, genişlemeye değil derinleşmeye başladı. ResNet, artık değerlerin (residual value) yani öğrenme sırasında öğrenme işleminin tam başarılı olamadığı değerlerin mevcudiyeti durumunda, bir önceki katmandan gelen çıktı değerinin bu değere eklenerek öğrenme işlemine katkıda bulunmasını mümkün kılan bir mimaridir.

\subsubsection{K-En Yakın Komşu}

Denetimli öğrenmede sıklıkla kullanılan bir makine öğrenmesi tekniğidir. Diğer denetimli öğrenme yöntemlerinin aksine eğitim kısmı yoktur. Bu algoritmada eğitim ve test neredeyse birbirine benzerdir. Sınıfları zaten belli olan örnek bir veri setinden faydalanarak kullanılır. Veri setine eklenmek istenen yeni verinin, diğer verilere olan uzaklı̆̆ı, kullanılan uzaklık türüne göre hesaplanır. K sayıdaki en yakın komşulara bakılır ve elde edilen sonuç hangisine yakınsa o veri grubuna göre etiketleme yapılır. Tüm olasılıklar hesaplandığı için donanım açısından oldukça maliyetlidir. Yüksek bellek gerektirir (Cover ve Hart, 1967).

\subsubsection{Yapay Sinir Ağları (YSA)}

Yapay Sinir Ağları (YSA), insanlara ait gerçek beyin fonksiyonlarının ürünü olan örneklerden yola çıkarak öğrenebilen ve bu öğrenmenin sonucunda kendi karşılaştı̆̆ sorunlar karşısında nasıl çözümler üretileceğini belirleyebilen sistemlerdir (Öztemel, 2006). YSA'lar insan beyninin çalışma prensibinden yola çıkılarak geliştirilmiştir. Yapay sinir hücreleri bir araya gelerek yapay sinir ağını oluştururlar. Bu hücrelerin bir araya gelmeleri tesadüfi değildir. Belli katmanlara ayrılıp, katmanların içerisinde paralel bir şekilde dizilerek sinir ağını meydana getirirler. Bir YSA'da genel olarak 3 tip katman bulunmaktadır:

Girdi Katmanı (Input Layer): Çevreden alınan bilgileri bir sonraki katmana (ara katmana) iletmekle görevlidirler. Bu katmanda herhangi bir bilgi işleme söz konusu değildir.

Ara Katman (Hidden Layer): Girdi katmanından alınan bilgiler bu katmanda işlenmektedir. Bir YSA'da birden fazla sayıda ara katman bulunabilir. Bilgi işleme sonrası, bilgiler bu katmandan çıktı katmanına gönderilir.

Çıktı Katmanı (Output Layer): Bu katmanda yer alan hücreler, ara katmandan gönderilen bilgileri işleyerek girdi katmanının çevreden aldığı bilgilere örnek teşkil etmesi gereken çıktıları üretir ve çevreye (dış dünyaya, kullanıcıya) gönderir (Öztemel, 2006).

YSA'larda girdi katmanından alınan bilgiler, ağırlıklar (weights) ile çarpılarak bir sonraki katmana (ara katman) aktarılır ve bir toplama fonksiyonundan geçirilirler. Bu durum, girdi katmanının tüm nöronlarından gelen bilgilerin ilgili ağırlıklar ile çarpılarak toplanmasıdır. Daha sonra çıkış katmanına varıncaya dek her ara katmanda bu işlem tekrar edilir ve buna "ileri besleme (feed forward)" denilir. Çıktı katmanına gelindiğinde ise bu değerler bir aktivasyon fonksiyonundan geçirilirler ve nihai çıktı elde edilir. Elde edilen son çıktı (tahmin edilen çıktı) ile olması gereken çıktı arasındaki fark "hata" olarak adlandırılır ve bu hata, istenen düzeye indirgenmek için geriye dönük olarak tüm ağa yayılır. Hatanın tüm ağa yayılması ise "geriye yayılım (back propagation)" olarak isimlendirilir. Burada amaç, ağırlıkların güncellenmesidir. İleri besleme ve geriye yayılım ile öğrenme işlemi gerçekleşmiş olur. Şekil 17'de YSA hücrelerinin yapısı gösterilmektedir.

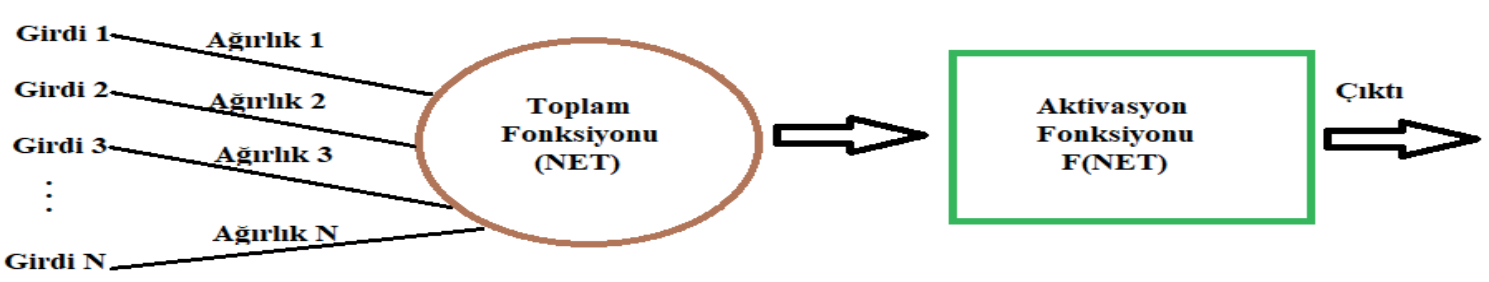

Şekil 17. YSA’nın yapısı

\subsubsection{SegNet}

SegNet, anlamsal bir bölütleme (segmentasyon) modelidir. Kodlayıcı (encoder) ve kod çözücü (decoder) katmanlardan oluşan 
bir yapıya sahiptir. SegNet üzerindeki kodlayıcılar evrişim ve yığın normalizasyon (batch normalization) işlemleri uygular. Bu işlemlerden sonra her çerçeveden çıkardığı indeks değerini saklar ve bu işlemlerin sonucunda elde ettiği sonuç üzerinde maksimum ortaklama işlemini gerçekleştirir. SegNet üzerindeki kodlayıcılar mimari açıdan VGG16 ağı ile aynıdır. Kod çözücüler ise düşük çözünürlüğe sahip kodlayıcı öznitelik haritalarını piksel temelli sınıflandırma yapmak için eksiksiz bir çözünürlüklü öznitelik haritalarına eşler. SegNet’in en önemli özelliği düşük çözünürlüğe sahip olan giriş görüntülerinin özniteliklerini yüksek örnekleme (upsampling) ile artırmaktır (Badrinarayanan, Kendall ve Cipolla, 2017). Şekil 18'de SegNet mimarisi ve yapılan işlemler sonucunda araçların ve çevrenin anlamsal bölütleme çıktısı verilmektedir.

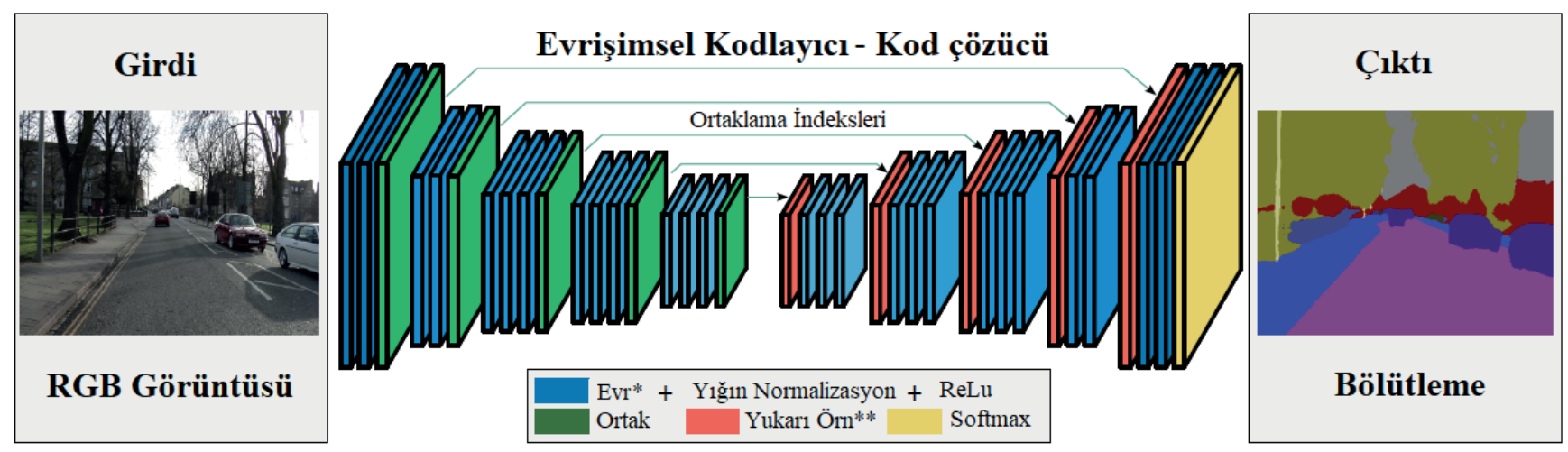

Şekil 18. SegNet mimarisi (Badrinarayanan, Kendall ve Cipolla, 2017).

Not: *=Evrişim, $* *=$ Yukarı örnekleme

\subsubsection{Dalgacık Dönüşümü (Wavelet Transform)}

Dalgacık dönüşümü, sinyallerin zaman-frekans gösteriminin sağlanması için kullanılan matematiksel bir dönüşüm türüdür (Alp, Akıncı ve Albora, 2008). Dalgacık dönüşümü esnasında ana dalgacığın muhtemel bütün ölçekleri ve sinyalin bütün zaman aralığı kullanıldığında hesaplanması gereken katsayılar oldukça büyük veri yığınlarına neden olur. Bu sebeple, belirli bazı ölçek ve konum aralıklarında dönüşüm gerçekleştirilir. Bu dönüşüm işleminin çok hızlı bir şekilde gerçekleşmesini sağlamak için ölçek ve konum verileri 2'nin üsleri olacak şekilde seçilir (Öner, Yeşilyurt ve Yılmaz, 2017; Alp, Akıncı ve Albora, 2008; Coşkun, 2019).

\subsubsection{U-net}

Derin öğrenme, genellikle çok sayıda veri ve bunların etiketlenmesi gibi süreçleri gerektirir. Özellikle elde edilmesi zor görüntülerde (tıbbi görüntü, uydu görüntüsü gibi) hem bu görüntülerin elde edilmesi hem de piksel bazlı konum verilerine ihtiyaç duyulmaktadır. Bu durum bazen sorunlara yol açabilir. U-net mimarisi, ESA katmanlarından oluşan ve YSA katmanı barındırmayan yapısı ile piksel bazlı görüntü bölütleme konusunda oldukça başarılı sonuçlar vermektedir. Şekil 19'da U-net model mimarisi verilmektedir. 


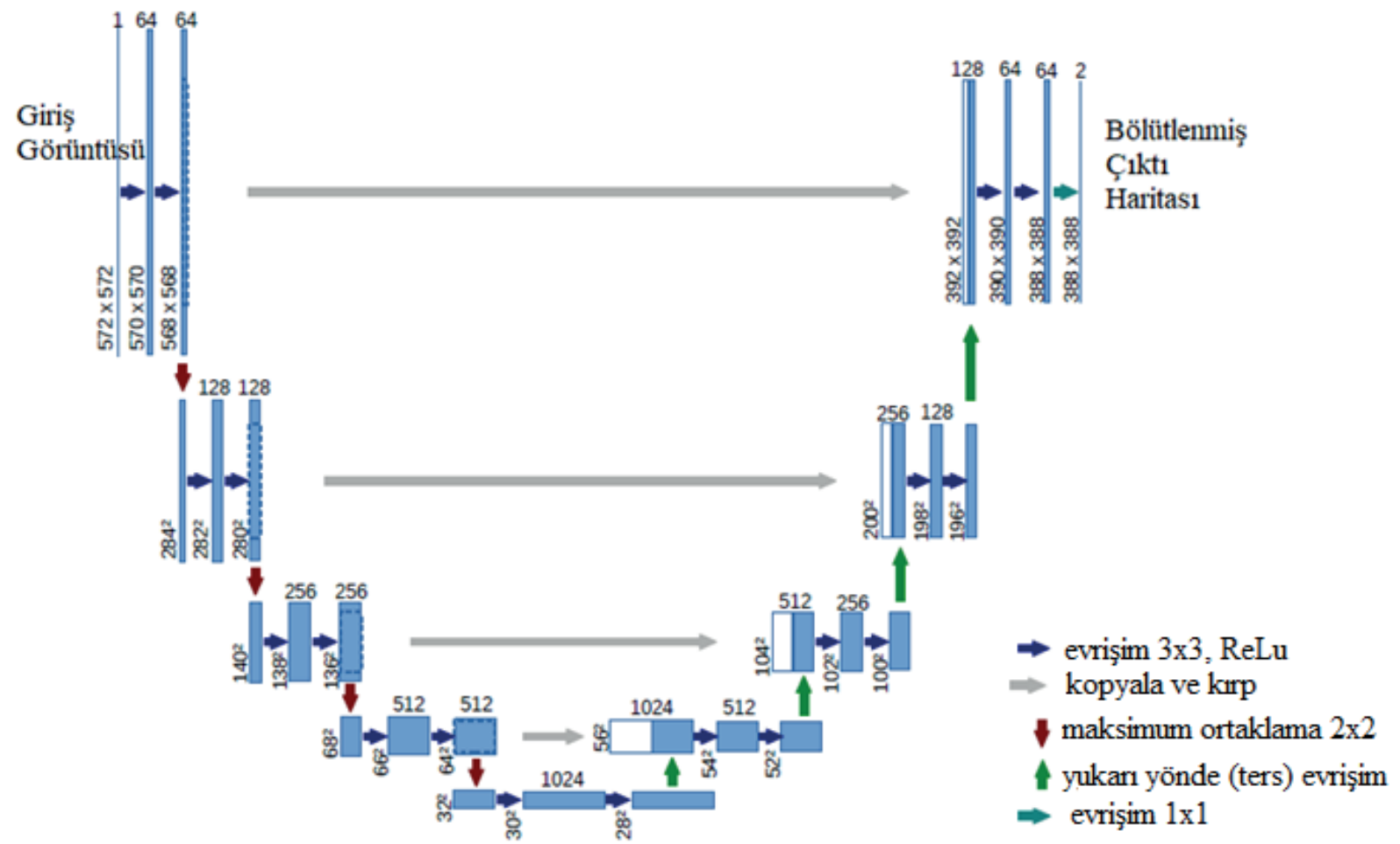

Şekil 19. U-net mimarisi (Ronneberger vd., 2015)

U-net modeli, Şekil 19'dan da görüleceği üzere adını model mimarisinden alır. U-net, aşağı yönde bir büzülme yolu (contracting path) ve yukarı yönde bir açılma yolundan (expansive path) oluşur. Büzülme yolunda, klasik ESA katmanlarının işlemleri meydana gelir. Bunlar sırasıyla iki defa 3x3'lük bir evrişim işlemi, geri dönüşümlü doğrusal birim fonksiyonu (ReLu) ve 2 adımlık (stride) bir 2x2'lik maksimum ortaklama işlemleridir. Açılma yolunda ise öznitelik kanallarını yarıya indiren 2x2'lik evrişim işlemi, büzülme yolundaki eş katmanlara karşılık gelen kırpılmış özellik eşleşmesi ile birleştirme işlemi ve 3x3’lük evrişim işleminin iki defa tekrarlanması işlemleri gerçekleşir (Ronneberger vd., 2015).

\subsection{7. Çekişmeli Üretici Ağlar (Generative Adversarial Networks)}

Derin öğrenme alanında, görüntü sınıflandırması, bölütleme, kümeleme vb. işlemler yapılmasına olanak sağlayan birçok model, mimari geliştirilmiştir. Çekişmeli Üretici Ağlar (ÇÜA), ilk defa görüntü üretebilen bir model ortaya koymuştur (Goodfellow ve ark., 2014). Klasik ESA’lardan farklı olarak ÇÜA, kendi içerisinde bir üretici (generative) ve bir ayırıcı (discriminator) olarak adlandırılan 2 farklı derin ağ barındırmaktadır. ÇÜA’nın işleyişi oldukça basittir. Üretici, veri setindeki görüntülerden yola çıkarak gerçek görüntülere benzeyen sentetik (sahte) görüntüler üretir ve ayırıcıyı kandırmaya çalışır. İki ağ arasında da bir nevi paralel bir rekabet (çekişme) vardır ve buna göre eğitilirler. Üretici ăg, belirli bir aşamadan sonra ayırıcı ağın ayırt edemeyeceği derecede yani gerçek görüntülere çok benzeyen görüntüler üretene kadar bu işlem devam eder. ÇÜA’lar son yıllarda üzerine en fazla çalışma yapılan derin öğrenme konularının başında gelmektedir (Goodfellow ve ark., 2014). Görüntü üretiminden video üretimine, çözünürlük artırımından doku sentezine varıncaya dek oldukça geniş bir yelpazeye ve başarılı sonuçlara sahiptir (Çelik ve Talu, 2019; Wu, Xu, Hall, 2017).

\subsection{Yöntemlerin Değerlendirilmesi}

Çalışmanın önceki alt bölümünde, Tablo 1'deki literatür çalışmalarında kullanılan yöntemlerin genel itibari ile yapısı anlatılmıştır. Bilgisayar donanımlarının gücünün gelişmesi ile beraber derin öğrenme alanında yapılan çalışmaların sayısı artmış ve içeriği oldukça zenginleşmiştir. Gerek makine öğrenmesinde gerek derin öğrenmede bir problem alanında kesin ve en iyi sonucu veren sabit bir yöntem ve parametre bulunmamaktadır. Elde edilen başarılı sonuçlara rağmen her geçen gün yapılan çalışmalar da bu değerlendirmeyi desteklemektedir. Ancak derin öğrenme alanında belirli görüntü veri setleri 
üzerinde sınıflandırma, bölütleme gibi amaçlarla geliştirilen modellerin parametre sayısı o modellerin tercih edilmesinde etkili olabilir. Çünkü bu parametreler doğrudan donanım gücü ile ilişkilidir. Ele alınan sorunun içeriğine, yapılmak istenen işleme ve çalışmanın amacına göre bir model ve parametre seçimi yapılabilir. Bu çalışmada verilen yöntemler birbirlerinden farklı sorunlara, amaçlara ve metriklere yönelik olduğu için bu yöntemlerin kıyaslanması eksik ve hatalı olacaktır. Burada asıl odaklanılması gereken nokta, genel itibari ile yapay zekânın tıbbi görüntüleme alanında ne denli geniş bir yelpazede kullanıldı̆̆ıdır.

\section{TARTIŞMA ve SONUÇ}

Günümüzde yapay zekânın kullanım alanları artmaktadır. Tıbbi görüntülemede yapay zekânın kullanımı sayesinde uzmanların farklı tıbbi görüntüleme teknolojilerinden elde edilen görüntüleri daha iyi yorumlaması, hastalık tanısı konulması gibi işlemler zaman ve maliyet açısından daha ekonomik kullanılmakta ve bu işlemlerin otomatikleştirilmesi sağlanmaktadır. Kullanılan enerji türüne göre tıbbi görüntüleme teknolojileri ve bunlardan elde edilen görüntüler ile bu görüntülerin yorumlanması da farklılık göstermektedir. Bu durum, uzmanların işini zorlaştırmaktadır. Bu nedenle tıbbi görüntüleme alanında yapay zekânın kullanımı ile ilgili çalışmalar gün geçtikçe artmakta ve geliştirilmektedir.

$\mathrm{Bu}$ çalışma, tıbbi görüntülemede yapay zekânın kullanımı ile ilgili yapılacak çalışmalara dair bir teorik bir temel inşa etmek ve genel bir bakış açısı sunmak için amacıyla hazırlanmıştır. Literatürde özellikle nükleer tıp görüntüleme başta olmak üzere tıbbi görüntüleme teknolojilerini kapsayan, bu teknolojileri açıklayan çalışmaların yetersiz olmasından dolayı söz konusu eksiklik bu çalışmada bir bütünlük içerisinde giderilmiştir. Ayrıca, tıbbi görüntülemede yapay zekâ kullanımının mevcut durumu, geleceği, bu alanda karşılaşılan sorunlar ve bunların çözümleri gibi hususların açık bir şekilde ele alınması, çalışmanın literatüre olan katkısını göstermektedir. Tıbbi görüntülemede yapay zekâ kullanımı tartı̧̧ma ve sonuç bölümünde ele alınmaması, bu durumun bir başlık altında özel olarak incelenmesi ve hemen arkasından tıbbi görüntülemede yapay zekâ kullanımın popüler ve işlevsel bir örneği olan bilgisayar destekli tanı sistemlerinin verilmesi, çalışmanın anlam bütünlüğünü sağlamaya yönelik özel bir tutumdur. Tıbbi görüntülemede yapay zekâ kullanımına ilişkin olarak Bilgisayar Destekli Tanı Sistemlerinin ve diğer gelişmelerin, sağlık çalışanlarının ve bilhassa doktorların rakibi olmayıp aksine onların yorum-teşhis gücünü artırmaya yönelik yardımcı uygulamalar olması hususuna değinilmiştir. Çalışmada sadece tıbbi görüntüleme teknolojileri açıklanmamış bu alanda yapay zekânın kullanımı ile ilgili her bir tıbbi görüntüleme tekniği için yapılmış güncel ve başarılı çalışmalar da sonuçları ile birlikte verilmiştir. Dolayısıyla literatürdeki tıbbi görüntüleme teknolojilerinin kapsayıcı, açıklayıcı ve yapay zekâ ile ilişkisinin net bir şekilde ortaya konulması ile ilgili boşluk, bu çalışma ile doldurulmaya çalışılmıştır.

İleriki çalı̧̧malarda tıbbi görüntü formatları, bu görüntülerin ön işleme ile nasıl kullanıma hazır hale getirildiği ve tıbbi görüntü veri setleri gibi konularda da çalışmaların gerçekleştirilmesi faydalı olacaktır. Özellikle gerçek tıbbi görüntülere erişim, bu alanda çalışan araştırmacılar için ciddi bir zorluktur. Bu sebeple, tıbbi görüntüleri açık erişime sunan hastaneler, vakıflar, kliniklerden elde edilen görüntüleri bir araya toplayan kişi ya da kurumların oluşturdukları açık veri setlerinin tanıtılması, tıbbi görüntülerin yapay zekâ ile işlenmesi ve çalışılması, ilgili konularda çalışan araştırmacılara büyük kolaylık sağlayacaktır.

Hakem Değerlendirmesi: Dış bağımsız.

Çıkar Çatışması: Yazarlar çıkar çatışması bildirmemiştir.

Finansal Destek: Yazarlar bu çalışma için finansal destek almadığını beyan etmiştir.

Peer-review: Externally peer-reviewed.

Conflict of Interest: The authors have no conflict of interest to declare.

Grant Support: The authors declared that this study has received no financial support. 


\section{Kaynaklar/References}

3 Boyutlu Mamogram Görüntüsü. WAKE RADIOLOGY. (2020, 8 Haziran). Erişim Adresi: https://www.wakerad.com/whats-new/ study-3-d-scans-accurate-standard-mammograms/

ABD’li ve Çinli şirketler Yapay Zekaya hükmetmek için yarışıyor. (2020, 17 Ekim). Erişim Adresi: https://www.wsj.com/articles/ why-u-s-companies-may-losethe-ai-race-1516280677

Alp, H., Akıncı, T. Ç., \& Albora, M. (2008). Jeofizik Uygulamalarda Fourier ve Dalgacık Dönüşümlerinin Karşılaştırılması. Pamukkale Üniversitesi Mühendislik Bilimleri Dergisi, 14(1), 67-76.

Al-shamasneh, A. R. M., \& Obaidellah, U. H. B. (2017). Artificial intelligence techniques for cancer detection and classification: review study. European Scientific Journal, 13(3), 342-370.

Arslan, T. X Işınları ve Kullanım Alanları. Gazi Üniversitesi Tezi, 2010.

Badrinarayanan, V., Kendall, A., \& Cipolla, R. (2017). Segnet: A deep convolutional encoder-decoder architecture for image segmentation. IEEE transactions on pattern analysis and machine intelligence, 39(12), 2481-2495.

Bailey, D. L., Maisey, M. N., Townsend, D. W., \& Valk, P. E. (2005). Positron emission tomography (Vol. 2). London: Springer.

Bankman, I. N. (2009). Handbook of medical image processing and analysis. Boston: Academic Press.

Bray, F., Ferlay, J., Soerjomataram, I., Siegel, R. L., Torre, A., \& Jemal, A. (2018). Global cancer statistics 2018: GLOBOCAN estimates of incidence and mortality worldwide for 36 cancers in 185 countries. CA: a cancer journal for clinicians, vol. 6, no. 8, pp. 394-424.

Buck, A. K., Nekolla, S., Ziegler, S., Beer, A., Krause, B. J., Herrmann, K., ... \& Drzezga, A. (2008). Spect/ct. Journal of Nuclear Medicine, 49(8), 1305-1319.

Budak, Ü. (2019). SegNet Mimarisi ile Bilgisayarlı Tomografi Görüntülerinden Karaciğer Bölgesinin Bölütlenmesi. Fırat Üniversitesi Mühendislik Bilimleri Dergisi, 31(1), 215-222.

Bushberg, J. T., Seibert, J. A., Leidholdt Jr, E. M., Boone, J. M., \& Goldschmidt Jr, E. J. (2011). Introduction to Medical Imaging. The essential physics of medical imaging. 3 rd edition: Lippincott Williams \& Wilkins.

Buxton, R. B. (2009). Introduction to Functional Magnetic Resonance Imaging Principles and Techniques. Cambridge: Cambridge University Press.

Cai, C., Wang, C., Zeng, Y., Cai, S., Liang, D., Wu, Y., Chen, Z., Ding, X. and Zhong, J. (2018). Single-shot T2 mapping using overlapping-echo detachment planar imaging and a deep convolutional neural network. Magnetic resonance in medicine, 80(5), 2202-2214.

Cheng, H. D., Cai, X., Chen, X., Hu, L., \& Lou, X. (2003). Computer-aided detection and classification of microcalcifications in mammograms: a survey. Pattern recognition, 36(12), 2967-2991.

Chow, J. C., Boyd, S. K., Lichti, D. D., \& Ronsky, J. L. (2020). Robust Self-Supervised Learning of Deterministic Errors in Single-Plane (Monoplanar) and Dual-Plane (Biplanar) X-ray Fluoroscopy. IEEE Transactions on Medical Imaging, 39(6), 2051-2060.

Coşkun, Y. (2019). Ayrık dalgacık dönüşümü tabanlı paralel görüntü sıkıştırma sistemi tasarımı (Master’s thesis, Maltepe Üniversitesi, Fen Bilimleri Enstitüsü).

Cover, T., \& Hart, P. (1967). Nearest neighbor pattern classification. IEEE transactions on information theory, 13(1), $21-27$.

Çelik, G., \& Talu, M. F. (2019). Çekişmeli üretken ağ modellerinin görüntü üretme performanslarının incelenmesi. Balıkesir Üniversitesi Fen Bilimleri Enstitüsü Dergisi, 22(1), 181-192.

Dandıl, E., Serin, Z. (2020). Derin Sinir Ağları Kullanarak Histopatolojik Görüntülerde Meme Kanseri Tespiti . Avrupa Bilim ve Teknoloji Dergisi , Ejosat Özel Say1 2020 (HORA): 451-463.

Deng, J., Berg, A., Satheesh, S., Su, H., Khosla, A., \& Fei-Fei, L. (2012). Imagenet large scale visual recognition competition 2012 (ILSVRC2012).

Doi, K. (2007). Computer-aided diagnosis in medical imaging: historical review, current status and future potential. Computerized medical imaging and graphics, 31(4-5), 198-211.

Dong, X., Lei, Y., Wang, T., Higgins, K., Liu, T., Curran, W. J., ... \& Yang, X. (2020). Deep learning-based attenuation correction in the absence of structural information for whole-body positron emission tomography imaging. Physics in Medicine \& Biology, 65(5), 055011.

Düzleştirme Katmanı ile görüntü matrislerinin vektör hâline getirilmesi. (2021, 14 Ocak). Erişim Adresi: https://medium.com/@tuncerergin/ convolutional-neural-network-convnet-yada-cnn-nedir-nasil-calisir-97a0f5d34cad

Ehrlich, Ruth Ann., Daly, Joan A. (2008). Patient Care in Radiography: With an introduction to medical imaging (Seventh Edition). MO: Elsevier.

El-Baz, A. S., \& Suri, J. S. (2019). Lung imaging and CADx. Boca Raton, FL: CRC Press/Taylor \& Francis.

El-Baz, A., Beache, G. M., Gimel'farb, G., Suzuki, K., Okada, K., Elnakib, A., ... \& Abdollahi, B. (2013). Computer-aided diagnosis systems for lung cancer: challenges and methodologies. International journal of biomedical imaging.

Ertel, W., Black, N., \& Mast, F. (2017). Introduction to artificial intelligence. Cham, Switzerland: Springer.

European Society of Radiology (ESR. (2015). ESR position paper on imaging biobanks. Insights into imaging, 6(4), 403-410.

Floroskopi Prosedürü ve Görüntüsü, Angela Betsaida B. Laguipo. (2020, 8 Haziran). Erişim Adresi: https://www.news-medical.net/health/FluoroscopyProcedure.aspx

Fotin, S. V., Yin, Y., Haldankar, H., Hoffmeister, J. W., \& Periaswamy, S. (2016, March). Detection of soft tissue densities from digital breast tomosynthesis: comparison of conventional and deep learning approaches. In Medical Imaging 2016: Computer-Aided Diagnosis (Vol. 9785, p. 97850X). International Society for Optics and Photonics.

Ghoneim, A., Muhammad, G., \& Hossain, M. S. (2020). Cervical cancer classification using convolutional neural networks and extreme learning machines. Future Generation Computer Systems. 102: 643-649. 
Gonzalez, Rafael (2018). Digital image processing. New York, NY: Pearson.

Goodfellow, I., Pouget-Abadie, J., Mirza, M., Xu, B., Warde-Farley, D., Ozair, S., ... \& Bengio, Y. (2014). Generative adversarial nets. Advances in neural information processing systems, 27, 2672-2680.

Greenspan, H., Van Ginneken, B., \& Summers, R. M. (2016). Guest editorial deep learning in medical imaging: Overview and future promise of an exciting new technique. IEEE Transactions on Medical Imaging, 35(5), 1153-1159.

Gulli, A., Kapoor, A., \& Pal, S. (2019). Deep learning with TensorFlow 2 and Keras: Regression, ConvNets, GANs, RNNs, NLP, and more with TensorFlow 2 and the Keras API. Birmingham: Packt Publishing.

Haidekker, M. A. (2013). Medical Imaging Technology. New York, NY: Springer.

He, K., Zhang, X., Ren, S., \& Sun, J. (2016). Deep residual learning for image recognition. In Proceedings of the IEEE conference on computer vision and pattern recognition (pp. 770-778).

Hou, W., Zhang, D., Wei, Y., Guo, J., \& Zhang, X. (2020). Review on Computer Aided Weld Defect Detection from Radiography Images. Applied Sciences, 10(5), 1878.

Huettel, S. A., Song, A. W., \& McCarthy, G. (2004). Functional magnetic resonance imaging (Vol. 1). Sunderland, MA: Sinauer Associates.

Hutton, L., \& Henderson, T. (2017). Beyond the EULA: Improving consent for data mining. In Transparent Data Mining for Big and Small Data (pp. 147-167). Cham: Springer International Publishing.

ILSVRC2012. Large Scale Visual Recognition Challenge 2012. (2020, 22 Aralık). Erişim Adresi: https://www.kdnuggets.com/2018/12/deep-learningmajor-advances-review.html

Imagenet’te Görüntü Sınıflandırması. (2020, 6 Eylül). Erişim Adresi: https://paperswithcode.com/sota/image-classification-on-imagenet

Kiani, A., Uyumazturk, B., Rajpurkar, P., Wang, A., Gao, R., Jones, E., ... \& Martin, B. A. (2020). Impact of a deep learning assistant on the histopathologic classification of liver cancer. NPJ digital medicine. 3(1): 1-8.

Krizhevsky, A., Sutskever, I., \& Hinton, G. E. (2012). Imagenet classification with deep convolutional neural networks. In Advances in neural information processing systems. 1097-1105.

Kubat, M. (2018). Introductıon To Machıne Learning. Place of publication not identified: SPRINGER INTERNATIONAL PU.

Lameka, K., Farwell, M. D., \& Ichise, M. (2016). Positron emission tomography. In Handbook of clinical neurology (Vol. 135, pp. 209-227). Amsterdam: Elsevier.

Larson, C., Lionhart, P., Roh, A., \& Colglazier, R. (2018). Introduction to fluoroscopy: For residents \& professionals alike. Place of publication not identified: Prometheus Liionhart.

LeCun, Y., Bottou, L., Bengio, Y., \& Haffner, P. (1998). Gradient-based learning applied to document recognition. Proceedings of the IEEE, 86(11), $2278-2324$

Leighton, T. G. (2007). What is ultrasound? Progress in biophysics and molecular biology, 93(1-3), 3-83.

Litjens, G., Kooi, T., Bejnordi, B. E., Setio, A. A. A., Ciompi, F., Ghafoorian, M., ... \& Sánchez, C. I. (2017). A survey on deep learning in medical image analysis. Medical image analysis, 42, 60-88.

Maulik, D., \& Zalud, I. (Eds.). (2005). Doppler ultrasound in obstetrics and gynecology (pp. 363-374). Berlin: Springer.

Mettler, F. A., \& Guiberteau, M. J. (2012). Essentials of nuclear medicine imaging. Philadelphia, PA: Elsevier/Saunders.

Morra, L., Delsanto, S., \& Correale, L. (2019). Artificial Intelligence in Medical Imaging: From Theory to Clinical Practice. Boca Raton: CRC Press.

Murino, V., Puppo, E., Sona, D., Cristani, M., \& Sansone, C. (Eds.). (2015). New Trends in Image Analysis and Processing--ICIAP 2015 Workshops: ICIAP 2015 International Workshops, BioFor, CTMR, RHEUMA, ISCA, MADiMa, SBMI, and QoEM, Genoa, Italy, September 7-8, 2015, Proceedings (Vol. 9281). Heidelberg: Springer.

Neri, E., \& Regge, D. (2017). Imaging biobanks in oncology: European perspective. Future Oncology, 13(5), $433-441$.

Ortaklama katmanı türleri. (2021, 14 Ocak). Erişim Adresi: https://towardsdatascience. com/a-comprehensive-guide-to-convolutional-neural-networks-the-eli5-way-3bd2b1164a53

Öner, İ. V., Yeşilyurt, M. K., \& Yılmaz, E. Ç. (2017). WAVELET ANALİZ TEKNİĞİ VE UYGULAMA ALANLARI. Ordu Üniversitesi Bilim ve Teknoloji Dergisi, 7(1), 42-56.

Öztad, E. (2020). Meme Kanseri Tespitinde Sınıflandırma ve Sinir Ağları Yöntemlerinin Karşılaştırılması. İleri Mühendislik Çalışmaları ve Teknolojileri Dergisi. 1(1): 49-54.

Öztemel, E. (2006). Yapay Sinir Ağları. 2. Baskı. Papatya Yayıncılık: İstanbul.

Pisano, E. D., \& Yaffe, M. J. Digital mammography. Radiology, vol. 234, no. 2, pp. 353-362, 2005.

Ranschaert, E. R., Morozov, S., \& Algra, P. R. (2019). Artificial Intelligence in Medical Imaging: Opportunities, Applications and Risks. Cham: Springer International Publishing.

Ronneberger, O., Fischer, P., \& Brox, T. (2015). U-net: Convolutional networks for biomedical image segmentation. In International Conference on Medical image computing and computer-assisted intervention (pp. 234-241). Springer, Cham.

Sağlık hizmetleri verileri ve gevşek kurallar Çin'in Yapay Zekâ konusunda başarılı olmasına nasıl yardımcı oluyor? (2020, 17 Ekim). Erişim Adresi: https://www.wired.com/story/health-care-data-laxrules-help-china-prosper-ai/

Sahiner, B., Pezeshk, A., Hadjiiski, L. M., Wang, X., Drukker, K., Cha, K. H., ... \& Giger, M. L. (2019). Deep learning in medical imaging and radiation therapy. Medical physics, 46(1), e1-e36.

Sarhan, A. M. (2020). Brain Tumor Classification in Magnetic Resonance Images Using Deep Learning and Wavelet Transform. Journal of Biomedical Science and Engineering, 13(06), 102. 
Sato, E., Nakayama, K., Nakamura, K., Ishikawa, M., Katagiri, H., \& Kyo, S. (2015). A case with life-threatening uterine bleeding due to postmenopausal uterine arteriovenous malformation. BMC Women's Health, 15(1), 1-5.

Shi, L., Onofrey, J. A., Liu, H., Liu, Y. H., \& Liu, C. (2020). Deep learning-based attenuation map generation for myocardial perfusion SPECT. European Journal of Nuclear Medicine and Molecular Imaging, 1-13.

Shia, W., \& Chen, D. (2020). Abstract P1-02-10: Using deep residual networks for malignant and benign classification of two-dimensional Doppler breast ultrasound imaging.

Shung, K. K. (2015). Diagnostic ultrasound: Imaging and blood flow measurements. Boca Raton, BR: CRC press.

Sluimer, I., Schilham, A., Prokop, M., \& Van Ginneken, B. (2006). Computer analysis of computed tomography scans of the lung: a survey. IEEE transactions on medical imaging, 25(4), 385-405.

Smith, N. \& Webb, A. (2010). Nuclear medicine: Planar scintigraphy, SPECT and PET/CT. In Introduction to Medical Imaging: Physics, Engineering and Clinical Applications (Cambridge Texts in Biomedical Engineering, pp. 89-144). Cambridge: Cambridge University Press. doi:10.1017/ CBO9780511760976.003

SPECT görüntüleri ile Alzheimer Hastalı̆̆ı Teşhisi. (2020, 10 Haziran). Erişim Adresi: https://www.pinterest.co.uk/pin/350717889706920247/

Szabo, T.L. Doppler Models. (2004). Diagnostic ultrasound imaging: inside out. 2 nd edition: Academic Press.

Talo, M. (2019, April). Pneumonia Detection from Radiography Images using Convolutional Neural Networks. In 2019 27th Signal Processing and Communications Applications Conference (SIU) (pp. 1-4). IEEE.

The Economist. "Çalışmamaktan Sinir Ağına”. (2020, 3 Eylül). Erişim Adresi: https://www.economist.com/special-report/2016/06/23/ from-not-working-to-neural-networking

The, L. (2018). Artificial intelligence in health care: within touching distance. Lancet (London, England), 390(10114), 2739.

Tiryaki, V. (2020). Mamografi görüntülerindeki anormalliklerin yerel ikili örüntü ve varyantları kullanılarak sınıflandırılması. Bitlis Eren Üniversitesi Fen Bilimleri Dergisi , 9 (1), 297-305 . DOI: 10.17798/bitlisfen.557411.

Vakanski, A., Xian, M., \& Freer, P. E. (2020). Attention-Enriched Deep Learning Model for Breast Tumor Segmentation in Ultrasound Images. Ultrasound in Medicine \& Biology, 46(10), 2819-2833.

Wang, H., \& Raj, B. (2017). On the origin of deep learning. arXiv preprint arXiv:1702.07800.

Webb, S., \& Flower, M. A. (2016). Webb's physics of medical imaging. Place of publication not identified: CRC Press.

Wilhelm Conrad Röntgen'in eşine ait ilk radyografi görüntüsü. (2020, 8 Ekim). Erişim Adresi: https://www.winally.com/2018/09/ yeni-nesil-goruntuleme/

Wu, X., Xu, K., \& Hall, P. (2017). A survey of image synthesis and editing with generative adversarial networks. Tsinghua Science and Technology, 22(6), 660-674.

Yapay Zekâ, Tıbbi Teşhise karşı. Teşhis otomatikleştirildiğinde ne olur? (2020, 15 Eylül). Erişim Adresi:https://www.newyorker.com/magazine/2017/04/03/ ai-versus-md

Zekâ teriminin tanımı. Türk Dil Kurumu. (10 Eylül, 2020). Erişim Adresi: https://www.sozluk.gov.tr (Erişim zamanı: 10.10.2020). 